\title{
Modelling of Domestic Hot Water End-Uses for Integrated Urban Thermal Energy Assessment and Optimisation
}

\author{
Alexandre Bertrand ${ }^{\mathrm{a}, \mathrm{b}, *}$, Alessio Mastrucci ${ }^{\mathrm{a}}$, Nils Schüler $^{\mathrm{b}}$, Riad Aggoune $^{\mathrm{c}}$, François Maréchal $^{\mathrm{b}}$ \\ ${ }^{a}$ Luxembourg Institute for Science and Technology - LIST, Environmental Research and Innovation, Belvaux, \\ Luxembourg \\ ${ }^{b}$ Swiss Federal Institute of Technology of Lausanne - EPFL, Industrial Process and Energy Systems Engineering, \\ Sion, Switzerland \\ ${ }^{c}$ Luxembourg Institute for Science and Technology - LIST, Information Technologies for Innovative Services, \\ Esch-sur-Alzette, Luxembourg
}

\begin{abstract}
Former integrated urban energy assessments and optimisation have modelled domestic hot water (DHW) demand as a single stream, as space heating, currently, is the main energy demand in buildings and a detailed DHW modelling was therefore not required. However, the characterisation of energy saving measures (e.g. grey water heat recovery) and the selection of optimal heating utility in buildings with low temperature space heating would benefit from a differentiation of the various DHW end-uses at urban scale. To this end, a new method modelling the main DHW appliances in households, hotels and nursing homes at urban level, is proposed. A review of European publications characterising water uses is conducted and utility load and energy consumption equations are developed. A specific model for district heating heat exchangers without thermal storage for integrated urban energy optimisation is proposed. The DHW-related energy consumption results are confirmed by typical values in a real urban case-study. Showering represents more than $80 \%$ of the DHW energy demand, and more than $97 \%$ of the total $\mathrm{DHW}$ heat use is required up to $40^{\circ} \mathrm{C}$. The proposed method contributes to urban energy assessments and optimisation by improving the level of detail of the outcomes and by strengthening their integrated approach.
\end{abstract}

Keywords: Urban energy assessment, Integrated energy optimisation, Domestic hot water end-uses, Modelling

\section{Nomenclature}

COP Coefficient Of Power

DH District Heating

DHW Domestic Hot Water

GIS Geographical Information System

MFB Multifamily Building

MUB Mixed-use Building

\footnotetext{
${ }^{*}$ Corresponding author at: LIST, 41, rue du Brill - L-4422 Belvaux, Luxembourg. Tel: +352 2758881

Email address: alexandre.bertrand@list.lu (Alexandre Bertrand)
} 


\section{OLS Ordinary Least Squares \\ SFB Single Family Building \\ SH Space Heating}

\section{Symbols}

\begin{tabular}{|c|c|}
\hline$b$ & specific bed number per room $\left[\mathrm{room}^{-1}\right]$ \\
\hline$c_{p}$ & heat capacity $\left[\mathrm{kJ} / \mathrm{kg}^{*} \mathrm{~K}\right]$ \\
\hline$d$ & use duration $[\mathrm{s}]$ \\
\hline$f$ & use frequency $\left[\right.$ capita $^{*}$ day $\left.^{-1}\right]$ \\
\hline$m$ & room occupancy [\%] \\
\hline$p$ & bed place occupancy [\%] \\
\hline$\dot{Q}$ & thermal load $[\mathrm{kW}]$ \\
\hline$Q$ & energy [kWh] \\
\hline$R^{2}$ & coefficient of determination [-] \\
\hline$r$ & room number r [-] \\
\hline$S_{n}$ & DHW simultaneity factor [-] \\
\hline$s$ & stay duration [day] \\
\hline$T$ & temperature $\left[{ }^{\circ} \mathrm{C}\right]$ \\
\hline$t$ & time t [hour] \\
\hline$\dot{V}$ & volumetric flow $\left[\mathrm{m}^{3} / \mathrm{s}\right]$ \\
\hline$x_{\text {floor }}$ & useful floor surface $\left[\mathrm{m}^{2}\right]$ \\
\hline$x_{o c c}$ & number of occupants [occupants] \\
\hline$x_{\text {type }}$ & building type $[-]$ \\
\hline$x_{\text {period,a }}$ & construction period a of buildings \\
\hline$y$ & dwelling energy consumption $[\mathrm{kWh} / \mathrm{a}]$ \\
\hline$\varepsilon$ & random error term [-] \\
\hline$\eta_{u t i l i t y}$ & utility efficiency [-] \\
\hline$\rho$ & density $\left[\mathrm{kg} / \mathrm{m}^{3}\right]$ \\
\hline$\sigma$ & end-use occurrence [\%] \\
\hline$v$ & random value for end-use geoallocation \\
\hline
\end{tabular}




\author{
Subscripts \\ b building $b$ \\ e end-use e \\ h household h \\ o occupant o \\ $\mathrm{t}$ time $\mathrm{t}$ \\ $\mathrm{u}$ unit $\mathrm{u}$
}

\title{
1. Introduction
}

Due to resource scarcity problems and growing environmental impacts, the European Union decided in 2014 to further increase its former $20 \%$ energy efficiency target to $30 \%$ for the year 2030 (Commission [1]). Cities are responsible for $75 \%$ of the global energy consumption, as well as between 50 to $60 \%$ of the green house gas emissions (UN Habitat [2]) and therefore play a central role in the global improvement of energy efficiency. In that sense, new buildings shall be designed in the EU to be near-zero energy until 2020 (European Parliament [3]). In 2012, space heating (SH) household final energy consumption amounted to 199.04 Mtoe, while domestic hot water (DHW) reached 37.72 Mtoe representing $16 \%$ of the total heat requirements - in the EU28 (Enerdata [4]). However, with improved thermal insulation, the relevance of DHW consumption is increasing. In the Netherlands, $23 \%$ of the household gas consumption is already related to DHW use, and new buildings see this contribution reach $50 \%$ of the energy consumption (Frijns et al. [5]).

So far, integrated urban energy assessments and optimisation mostly focused on the characterisation of space heating, and did not differentiate between the various DHW end-uses like showering, dish washing, etc. (Jennings et al. [6], Fonseca and Schlueter [7], Nouvel et al. [8]). Nevertheless, such a differentiation is conducted by Yao and Steemers [9], although relevant streams (shower and bath) are still aggregated as one stream, and by Aydinalp et al. [10], Widen et al. [11], Beal et al. [12], where the specific temperature levels of the various end-uses are not considered specifically. However, the differentiation and characterisation of DHW streams is of importance for an integrated approach to urban energy assessment and optimisation. With the distinction of the multiple domestic hot water end-uses, various energy saving measures can be more specifically addressed in an integrated way at urban scale. In particular, various grey water heat recovery configurations, as described by Schmid [13], McNabola and Shields [14], Dong et al. [15] for buildings or by Abdel-Aal et al. [16], Elias-Maxil et al. [17], Hepbasli et al. [18] for sewer systems, requires the characterisation of the specific DHW streams. The characterisation of the various end-use temperatures also improves the modelling of the heating utility temperature level of buildings with low temperature space heating systems, as this level is determined by the DHW demand (Brand et al. [19]). So far, the hot water temperature level has generally been assumed at $60^{\circ} \mathrm{C}$ (Perry et al. [20], Girardin et al. [21], Kordana et al. [22]), but with more specific DHW models, this level can actually be lowered. This again influences the selection of the optimal utility configuration, where heat pumps and low temperature waste heat recovery can become more competitive compared to biomass of fossil fuels. Finally, urban energy integration focusing on the optimisation of district heating (DH) systems only considered buildings equipped with hot water storage system (Weber [23], Fazlollahi [24], Elmegaard et al. [25]), although Thorsen and Kristjansson 
[26], Christiansen et al. [27], Rosa et al. [28] showed that a configuration without storage (stand-alone heat exchanger) can be equivalent or even better in terms of costs and energy efficiency. The modelling of such a configuration, however, requires the characterisation of the DHW loads according to the main end-uses.

Considering the above-mentioned shortcomings, the objective of this work is to propose a detailed urban DHW modelling method differentiating between the various end-uses encountered in domestic buildings (households) and lodgings (hotels and nursing homes), and characterising them according to their temperature levels. Based on these DHW models, a complementary method to calculate the load of DH stand-alone heat exchangers is formulated. The main contributions of the proposed method are therefore to increase the detail level of urban thermal energy assessments, as well as to improve integrated urban energy optimisation with the consideration of DHW temperature for optimal heating utility type selection and an additional district heating system configuration.

To this end, the modelling methodology to characterise the energy demand and load requirement of various DHW end-uses is presented in section 2. The equations for households, hotels and nursing homes are developed, and a review on European domestic water use is conducted. In section 3, the proposed modelling method is applied to the households, hotels and nursing homes of the city of Esch-sur-Alzette (Grand-Duchy of Luxembourg), where the DHW energy demands are calculated and compared to literature values. The energy use of the various DHW streams are also put in relation to the total and space heating energy demand in this case-study. Temperature level and utility load requirements as well as the impact of the proposed DHW models on the energy integration of heat pumps are finally addressed in this section. Considering the outcomes of the case-study, section 4 covers the advantages, shortcomings and main contributions of the proposed method, while conclusions are drawn in the final section.

\section{Method}

This section describes the proposed method for urban DHW modelling. In section 2.1, equations for the DHW-related energy consumption in function of occupant and units number (e.g. a household in multifamily buildings, a room in a hotel), space heating energy demand as well as the utility load of stand-alone heat exchangers are developed. A review of European literature on the characterisation of domestic water use, considering typical flows, use frequency and duration, temperature and occurrence is conducted in section 2.2. The geoallocation of the data is also presented in that section.

\subsection{Domestic hot water modelling methodology}

\subsubsection{DHW end-use load}

The thermal power requirement $\dot{Q}_{e}^{D H W}$ of a DHW end-use $e$ is calculated considering its density $\rho$, its heat capacity $c_{p}$, the hot water volumetric flow $\dot{V}_{e}^{h w}$ and the difference between hot and fresh water temperatures $\left(T_{\text {out }, e}^{h w}-T_{\text {in }}^{\text {fresh }}\right.$ ) (eq.1). Both volumetric flow and hot water temperature are specific to the considered end-use $e$.

$$
\dot{Q}_{e}^{D H W}=\rho \times c_{p} \times \dot{V}_{e} \times\left(T_{\text {out }, e}^{h w}-T_{\text {in }}^{\text {fresh }}\right)
$$

\subsection{2. $D H W$ and $S H$ energy demand}

2.1.2.1. Domestic buildings. The daily energy demand $Q_{e}^{D H W}$ of a DHW end-use $e$ is the product of the thermal power $\dot{Q}_{e}^{D H W}$ with its use duration $d_{e}$ and daily use frequency $f_{e}$.

$$
Q_{e}^{D H W}=\dot{Q}_{e}^{D H W} \times d_{e} \times f_{e}
$$


In a household, some of the DHW end-uses $e$ are related to the activities of the occupant $o$ (e.g. showering, bathing, washing and shaving), while other streams (e.g. dish washing) are directly linked

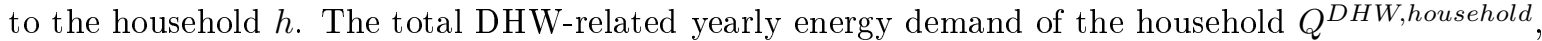
expressed in $\mathrm{kWh}$, is therefore obtained by summing the daily energy consumption $Q_{e, o, t}^{D H W}$ of the various DHW streams $e$ of occupant $o$ for time $t$, with the energy use $Q_{e, h, t}^{D H W}$ required at household level $h$ for time $t$ (eq.3).

$$
Q^{D H W, \text { household }}=\sum_{t=1}^{365}\left(\sum_{e} Q_{e, h, t}^{D H W}+\sum_{o} \sum_{e} Q_{e, o, t}^{D H W}\right)
$$

For multifamily buildings, some DHW end-uses (e.g. cleaning of common spaces) are required at building $b$ level. The yearly DHW energy demand $Q^{D H W, \text { building }}$ of a building is therefore obtained by summing up the DHW energy demand $Q_{e, o, h, b, t}^{D H W}$ of the occupants, $Q_{e, h, b, t}^{D H W}$ of the households and $Q_{e, b, t}^{D H W}$ of the streams attributed to the building common areas over 365 days (eq.4).

$$
Q^{D H W, \text { building }}=\sum_{t=1}^{365}\left[\sum_{e} Q_{e, b, t}^{D H W}+\sum_{h}\left(\sum_{e} Q_{e, h, b, t}^{D H W}+\sum_{o} \sum_{e} Q_{e, o, h, b, t}^{D H W}\right)\right]
$$

2.1.2.2. Lodgings. While the equations above can also be applied to hotels and nursing homes (the room replacing the household), the necessary input data are scarce. An alternative to eq.4 can be used, considering several parameters related to room and bed occupancies:

- the total room number $r$,

- the yearly room occupancy $m$, expressed in percentage,

- the average bed number per room $\beta$,

- the yearly bed place occupancy $p$, expressed in percentage.

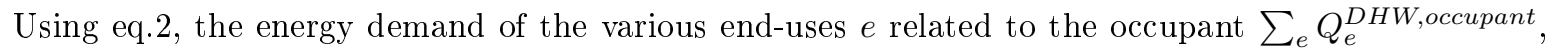
room $\sum_{e} Q_{e}^{D H W, \text { room }}$ and building $\sum_{e} Q_{e}^{D H W, \text { building }}$ are summed up according to the number of occupants (product of bed number per room and bed place occupancy) and the number of occupied rooms (product of number of rooms and room occupancy) for the whole year (eq.5).

$Q^{D H W, \text { lodging }}=365 \times\left[\sum_{e} Q_{e}^{D H W, \text { building }}+r \times\left(m \times \sum_{e} Q_{e}^{D H W, \text { room }}+\beta \times p \times \sum_{e} Q_{e}^{D H W, \text { occupant }}\right)\right]$

2.1.2.3. Space heating energy demand. With the characterisation of the DHW energy consumption, the space heating energy consumption is calculated considering the total fuel consumption and the efficiency of the heating utility $\eta_{\text {utility }}$ (eq.6).

$$
Q^{S H, \text { building }}=\left(Q^{\text {total }} \times \eta_{\text {utility }}\right)-Q^{D H W, \text { building }}
$$

In case measured data are not available, the total heat consumption can be conveniently determined using multiple regression analysis out of a sample of measured consumption data. Multiple linear regression is one of the different techniques available to predict the energy consumption of buildings based on measured consumption data as well as a series of predictors and has been used by several authors (Guerra Santin et al. [29], Howard et al. [30], Mastrucci et al. [31], Wahlstrom and Harsman [32], Schueler et al. [33]). Compared to other techniques, linear regression is particularly promising for this goal due to reasonable accuracy and relatively simple implementation (Fumo and Biswas [34]). 


\subsubsection{Utility load calculation}

2.1.3.1. Utility with thermal storage. The large majority of heating utilities in buildings cover both domestic hot water and space heating demands (Schramek [35])), and are usually used in combination with a hot water storage system. With the space heating energy consumption and data on outdoor temperature, the space heating load requirements can be obtained using the heating signature method (Girardin et al. [21]). The decentralised utility load (eq.7) is obtained by summing the maximal space heating load $\dot{Q}_{m a x}^{S H}$ and the continuous, averaged over 8'760 hours, DHW load (Schramek [35], Girardin et al. [21]). It is referred to the work of Becker and Marechal [36], Fazlollahi et al. [37, 38] for the optimised design of thermal storage tanks.

$$
\dot{Q}^{u t i l i t y, w . s t o r a g e}=\dot{Q}_{\max }^{S H}+\frac{Q^{D H W, b u i l d i n g}}{8760}
$$

2.1.3.2. Utility without hot water storage. Buildings connected to a district heating network are not necessarily equipped with a local DHW storage system (Christiansen et al. [27], Rosa et al. [28], Tol and Svendsen [39]). In literature, several methods to design the heat exchanger (HE) are proposed: while Gaderer [40], Tol and Svendsen [39] add up both SH and DHW load, Rosa et al. [28] considers only DHW, and Thorsen and Kristjansson [26] proposes to design the HE according to the highest load between DHW and SH. Considering building thermal inertia and the short DHW pulse duration, the approach of Thorsen and Kristjansson [26] is used for this work (eq.8).

$$
\dot{Q}^{u t i l i t y, n o \text { storage }}= \begin{cases}\dot{Q}^{u t i l i t y, D H W} & \text { if } \dot{Q}^{u t i l i t y, S H}<\dot{Q}^{u t i l i t y, D H W} \\ \dot{Q}^{u t i l i t y, S H} & \text { if } \dot{Q}^{u t i l i t y, S H}>\dot{Q}^{u t i l i t y, D H W}\end{cases}
$$

To determine the DHW power requirements of one household, the load of the DHW end-use with the highest value is selected and multiplied by a simultaneity factor $S=1.15$ (Schramek [35]). It is considered that the various large end-uses (e.g. bathtub, dish-washing and showering in households) are available once and are not used simultaneously, but that smaller end-uses can be required at the same time than a large DHW appliance (eq.9).

$$
\dot{Q}^{D H W, \text { household }}=1.15 \times \dot{Q}_{\max }^{D H W}
$$

For multifamily buildings, mixed-use buildings and lodgings, the DHW thermal power requirement at building level is not obtained by summing up the loads of the single end-uses of the $u$ units, as not all hot water demands occur at the same time (Thorsen and Kristjansson [26], Schramek [35]). Instead, in order to avoid an over-sizing of the utility, and thus higher investment costs, a simultaneity factor $S_{u}$ is considered, which is multiplied by the sum of the single largest hot water end-use $\dot{Q}_{u, \max }^{u n i t}$ of each unit u (eq.10).

$$
\dot{Q}^{D H W, \text { building }}=S_{u} \times \sum_{u} \dot{Q}_{u, \max }^{u n i t}
$$

The simultaneity factor $S_{u}$ is determined according to the number of units $u$ in the building. $S_{n}$ values are based on empirical data, and several models have been proposed to describe its behaviour (see Gaderer [40] and Christiansen et al. [27] for comparisons of simultaneity factor models). The simultaneity factors $S_{u}$ using the equations provided by Thorsen and Kristjansson [26] and Gaderer [40] are represented in fig.1.

Considering that the equation of Thorsen and Kristjansson [26] has been specifically designed for Danish hot water utility design conditions $(32.3 \mathrm{~kW})$ and that the results are still overestimated when compared to measured data (Thorsen and Kristjansson [26], Christiansen et al. [27]), the equation of Gaderer [40] is selected (eq.11). 


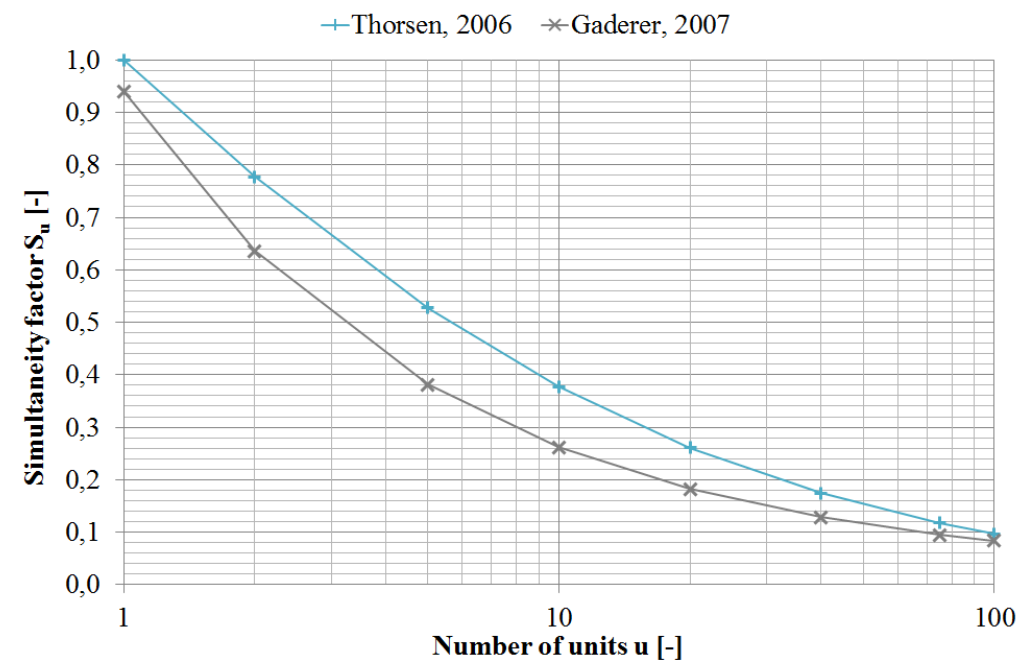

Figure 1: Simultaneity factors according to Thorsen and Kristjansson [26] and Gaderer [40]

$$
S_{u}=0.02+0.92 u^{(-0.58)}
$$

\subsection{Input data}

In order to apply the proposed method, the following input data are required:

- End-use temperature,

- Volumetric flow for load calculation,

- Use frequency and duration,

- Geographical allocation of end-uses, occupants and unit numbers.

\subsubsection{Temperatures}

The inlet temperature of fresh water $T_{i n}^{\text {fresh }}$ varies over the seasons between $5^{\circ} \mathrm{C}$ and $15^{\circ} \mathrm{C}$, but is, for yearly assessments, generally assumed at $10^{\circ} \mathrm{C}$ (Spur et al. [41], Widen et al. [11]). End-use temperature data are generally scarce. Yao and Steemers [9] and Schramek [35] give identical end-use temperatures for bath and shower, hand washing and dish washing (table 1), while Wong et al. [42] mentions an average temperature of $40.9^{\circ} \mathrm{C}$ for showers.

\subsubsection{DHW volumetric flows}

Volumetric flow data for European DHW end-uses are summarised for domestic and lodging buildings in tabs.2 and tabs.3, respectively. Widen et al. [11] provides water consumption of 25 different DHW streams, of which three, indicated in tabs.2, have a particularly high energy consumption. For non-European data, it is referred to DeOreo et al. [43], Hendron and Burch [44], Neunteufel et al. [45], Beal et al. [46], Cahill et al. [47], Kenway et al. [48], Rathnayaka et al. [49], Makki et al. [50].

Concerning household DHW streams, a value around 0.13-0.14 l/s for showers appears to be common. For bathtubs, the volumetric flow depends of the considered volume. The volumetric flow of kitchen sinks revolves around $0.1 \mathrm{l} / \mathrm{s}$, although lower and higher values are reported. Bathroom sink volumetric flow data show the largest variance, with values between 0.03 and $0.1 \mathrm{l} / \mathrm{s}$. 
Table 1: DHW end-use temperatures (Yao and Steemers [9], Schramek [35])

\begin{tabular}{lc}
\hline End-use type [-] & $\begin{array}{c}\text { End-use } \\
\text { temperature } \\
{\left[{ }^{\circ} \mathrm{C}\right]}\end{array}$ \\
\hline \hline Hand washing & 35 \\
\hline Washing and shaving & 35 \\
\hline Dish washing & 55 \\
\hline Showering & 40 \\
\hline Bath filling & 40 \\
\hline
\end{tabular}

\subsubsection{Use duration and frequency}

While data on volumetric flow of DHW are available in the literature, European data on use frequency and duration (tabs.4 and tabs.5, respectively) are scarce. Blokker et al. [52] mentions a total kitchen tap use frequency of 12.6 (household day) ${ }^{-1}$, which is subdivided between hand washing and dish washing at one fourth each, according to the penetration rate mentioned in the publication (the remaining $50 \%$ water use is for drinking, cooking, etc.). The tap use frequency of Neunteufel et al. [45] is distributed evenly between kitchen and bathroom sinks. Data on bathtub and shower use frequencies in non-European countries are given by Hokoi et al. [56], Kenway et al. [48].

\subsubsection{DHW streams occurrences and geoallocation}

The occurrence of a dish-washing machine or a bathtub in a household or a room is not automatically given (Blokker et al. [52]). As DHW end-use occurrence data are unlikely to be available at building level when conducting an urban energy assessment, it is proposed to geographically distribute these end-uses randomly in function of the appliance occurrences $o_{e}$ and by attributing random values $\varepsilon_{e}$ between 0 and 1 to each end-uses in the household, e.g. using the RANDOM function in PostgreSQL [57]. The end-use is considered installed for $\varepsilon_{e}<o_{e}$ (eq.12).

$$
\dot{Q}_{e}^{D H W}= \begin{cases}\dot{Q}_{e} & \text { if } \varepsilon_{e}<o_{e} \\ 0 & \text { if } \varepsilon_{e}>o_{e}\end{cases}
$$

Values on the occurrence of dishwasher $\mathrm{O}_{\text {dishwasher }}$ in households can be obtained from the respective national statistic agency (tab.6). Hand washing DHW demand is excluded for households equipped with a dishwasher.

Concerning the occurrence $o_{\text {bath }}$ of household bathtubs, data is rare. $97.5 \%$ of the EU27 households in 2013 were equipped with a shower or a bathtub (Eurostat [63]) but a further breakdown between these two end-uses is almost non-existing in European and national household or production statistics. The French national statistic agency indicates that $74.4 \%$ of the households were equipped with a bathtub in 2006, and 24.0\% with only a shower (INSEE [64]). A study on the water consumption in Austrian households showed that at least $25 \%$ of the 24 assessed households only used a shower (Neunteufel et al. [45]). Blokker et al. [52] indicate a dissemination rate of $36 \%$ for household bathtubs in the Netherlands. A survey conducted in China showed that between 20 to $100 \%$ of the households in Nanjing and around $70 \%$ of the Hefei households were only equipped with a shower (Hokoi et al. [56]).

Information on DHW appliance of non-residential buildings are also very scarce (Pieterse-Quirijns et al. [65], Blokker et al. [66]). Data on lodging bathtubs availability can be obtained from the site 
Table 2: Domestic DHW volumetric flows, in 1/s

\begin{tabular}{|c|c|c|c|c|c|c|c|c|}
\hline Reference & $\begin{array}{c}\text { Koiv } \\
\text { and } \\
\text { Toode } \\
{[51]}\end{array}$ & $\begin{array}{c}\text { Thorsen } \\
\text { and Krist- } \\
\text { jansson } \\
{[26]}\end{array}$ & $\begin{array}{c}\text { Schramek } \\
{[35]}\end{array}$ & $\begin{array}{l}\text { Widen } \\
\text { et al. } \\
{[11]}\end{array}$ & $\begin{array}{c}\text { Blokker } \\
\text { et al. } \\
{[52]}\end{array}$ & $\begin{array}{l}\text { Neunteufel } \\
\text { et al. } \\
{[45]}\end{array}$ & $\begin{array}{c}\text { Neunteufel } \\
\text { et al. } \\
{[45]}\end{array}$ & $\begin{array}{c}\text { Gutierrez- } \\
\text { Escolar } \\
\text { et al. } \\
{[53]}\end{array}$ \\
\hline Pub. year & 2006 & 2006 & 2007 & 2009 & 2010 & 2012 & 2012 & 2014 \\
\hline Country & Estonia & Denmark & Germany & Sweden & Netherland & s Austria & $\mathrm{EU}$ & Spain \\
\hline $\begin{array}{l}\text { Bathroom } \\
\text { sink }\end{array}$ & - & - & $\begin{array}{l}0.05 / \\
0.083^{\mathrm{a}}\end{array}$ & - & $0.04^{f}$ & 0.03 & - & $\begin{array}{c}0.07^{*} \\
0.1\end{array}$ \\
\hline $\begin{array}{l}\text { Kitchen } \\
\text { sink }\end{array}$ & 0.2 & 0.1 & $0.1 / \mathrm{b} 0.17$ & $39 \mathrm{l}^{\mathrm{d}}$ & $\begin{array}{l}0.08 / \\
0.13 \mathrm{~g}\end{array}$ & 0.03 & - & $\begin{array}{c}0.1 * \\
0.13\end{array}$ \\
\hline Shower & 0.2 & 0.14 & 0.14 & $\begin{array}{c}0.13 / \\
0.2 / \\
0.58^{\mathrm{e}}\end{array}$ & $\begin{array}{c}0.12^{*} \\
0.14\end{array}$ & 0.13 & 0.13 & $\begin{array}{c}0.17 \\
0.25\end{array}$ \\
\hline Bathtub & 0.3 & 0.21 & $\begin{array}{l}0.11 / \\
0.17 / \\
0.21 \mathrm{c}\end{array}$ & $\begin{array}{c}100 \\
1 / \text { bath }\end{array}$ & $0.20^{\mathrm{h}}$ & $\begin{array}{c}76 \\
\text { 1/bath }\end{array}$ & $\begin{array}{c}150 \\
1 / \text { bath }\end{array}$ & $\begin{array}{c}250 \\
1 / \text { bath }\end{array}$ \\
\hline 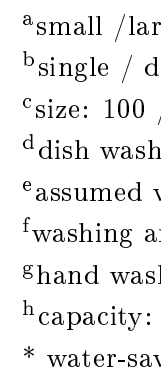 & $\begin{array}{l}\text { sink } \\
\text { ble sink } \\
160 / 180 \\
\mathrm{~g}, \text { mix of t } \\
\text { ue / moder } \\
\text { shaving } \\
\mathrm{gg} / \mathrm{dish} w \\
20 \mathrm{l} \\
\mathrm{g} \text { end-use }\end{array}$ & $\begin{array}{l}\mathrm{b} \text { and running } \\
\text { tap / trad. } \mathrm{t} \\
\text { shing }\end{array}$ & $\begin{array}{l}\text { vater } \\
\text { p }\end{array}$ & & & & & \\
\hline
\end{tabular}

manager, from the site homepage or reservation service homepage. While Pieterse-Quirijns et al. [65] considers both showers and bathtubs available in Dutch hotel rooms, the number of hotel bathtubs in the USA has strongly decreased with newer constructions. In 2001, 95\% of the Holiday Inn hotels were equipped with bathtubs, but hotels have recently been built either without (Indigo hotel) or only with a much smaller ratio varying between 25\% (Marriott) to 55\% (Holiday Inn) (Jones [67]).

\subsubsection{Occupant and unit geoallocation}

Inhabitant and household numbers can either be directly obtained from Geographical Information System (GIS) data sets or by using population census data. For lodgings, the best option to obtain the required data is to contact the facility manager, a solution which is nevertheless time-consuming and yields only a limited number of returns (Neunteufel et al. [45]). Should the detailed data not be available, public sources and statistical averages can be used to estimate the energy consumption. For hotels, national or regional tourism offices as well as reservation service homepage can provide the number of rooms r (e.g. Vienna Tourist Board [68], ONT [69], Switzerland Tourism [70]). Eurostat provides national and regional data on bedroom and bed place numbers, so that a specific bed number per room $\beta$ (Eurostat [71]) as well as the net bed places occupancy p (Eurostat [72]) are available. Nursing home room and bed numbers can be obtained from dedicated internet sites (e.g. Bundesministerium fur Arbeit, Soziales und Kosumentenschutz [73], Capgeris [74], Privatinstitut für Transparenz 
Table 3: Lodging DHW volumetric flows, in 1/s

\begin{tabular}{lcc}
\hline Reference & Cobacho et al. [54] & Blokker et al. [55] \\
\hline \hline Pub. year & 2005 & 2011 \\
\hline Country & Spain & Netherlands \\
\hline Building type & Hotel & Hotel, nursing home, \\
\hline Bathroom sink & $15.26 \mathrm{l} /$ day* guest $^{*}$ & $0.08^{\mathrm{a}}$ \\
\hline Showering & $13.03 \mathrm{l} /$ day*guest & $0.12 / 0.14 / 0.37^{\mathrm{b}}$ \\
\hline Bath filling & - & $0.20^{\mathrm{c}}$ \\
\hline $\begin{array}{l}\text { a } \text { hand washing, washing and shaving } \\
{ }^{\mathrm{b}} \text { water-saving/normal/comfort } \\
{ }^{\mathrm{c}} \text { capacity: } 120 \mathrm{l}\end{array}$
\end{tabular}

im Gesundheitswesen GmbH [75], Haederli et al. [76], Luxsenior [77]). Occupancy rate in Europe is very high, with values in Luxembourg, Italy and France reaching 95.4\% (Statec [78]), $93-98 \%$ and $98 \%$, respectively (Evans et al. [79]).

\section{Case-study}

The proposed DHW modelling method is applied to the residential buildings of the city of Esch-surAlzette (Esch), comprising the domestic buildings, the five hotels and the two nursing homes. The city has a population of 33'487 inhabitants and 14'321 households, distributed over 18 districts (Service des travaux municipaux [80]). The main data source is the city GIS data set, imported into a PostgreSQL geospatial database (PostgreSQL [57]) using the PostGIS extension (PostGIS Project [81]). The data set contains data on inhabitant and household numbers, year of construction, building footprint and floor number.

In order to assess the impact of DHW energy consumption on low energy and passive buildings (not included in the city assessment due to insufficient data on recent constructions from Statec [82]), these building types are considered specifically. An average inhabitant number for single family buildings (SFB) and multifamily buildings (MFB) of, respectively, 2.98 and 12 as well as an average household number of 1 and 5.48 is used.

The calculations deployed for the case-study are described in section 3.1. The results are presented in section 3.2.

\subsection{Calculations}

In section 3.1.1, the calculation of the various DHW energy demands of the households and lodgings of Esch is set up using the proposed modelling method. In order to validate the outcomes of the method, DHW energy demand using a surface-related approach is also used. The method to quantify this surface is included in this section. To put the impact of the various DHW streams in relation to the urban heat demand, the total heat consumption using linear regression is described in section 3.1.2. Section 3.1.3 describes how space heating energy requirements are obtained from total heat and DHW energy consumption. The calculation of space heating and utility load of stand-alone heat exchangers in district heating systems are formulated in section 3.1.4. Finally, heat pump energy integration according to various hot water temperature levels is addressed in section 3.1.5. 
Table 4: DHW use frequencies, in capita $\mathrm{x}_{\text {day }}{ }^{-1}$

\begin{tabular}{lccccc}
\hline Reference & $\begin{array}{c}\text { Cobacho et al. } \\
{[54]}\end{array}$ & $\begin{array}{c}\text { Blokker et al. } \\
{[52]}\end{array}$ & $\begin{array}{c}\text { Blokker et al. } \\
{[55]}\end{array}$ & $\begin{array}{c}\text { Neunteufel } \\
\text { et al. [45] }\end{array}$ & $\begin{array}{c}\text { Neunteufel } \\
\text { et al. [45] (EU) }\end{array}$ \\
\hline \hline $\begin{array}{l}\text { Building } \\
\text { type }\end{array}$ & Hotel & Household & $\begin{array}{c}\text { Offices, hotel, } \\
\text { nursing home, } \\
\text { restaurant }\end{array}$ & Household & Household \\
\hline $\begin{array}{l}\text { Bathroom } \\
\text { sink }\end{array}$ & $\begin{array}{c}5.36 \\
\text { /day*guest }\end{array}$ & $1.35^{\mathrm{a}}$ & $4.5 / 1.98^{\mathrm{c}}$ & 11.5 & - \\
\hline $\begin{array}{l}\text { Kitchen } \\
\text { sink }\end{array}$ & - & $3.150^{\mathrm{b}}$ & - & 11.5 & - \\
\hline $\begin{array}{l}\text { Showering } \\
\text { /day*guest }\end{array}$ & 0.70 & $0.20 / 0.80^{\mathrm{d}}$ & 0.7 & 0.8 \\
\hline $\begin{array}{l}\text { Bath } \\
\text { filling }\end{array}$ & - & 0.04 & $0.2^{\mathrm{e}}$ & 0.03 & 0.1 \\
\hline
\end{tabular}

${ }^{a}$ washing and shaving

${ }^{b}$ hand and dish washing, per household

${ }^{c}$ hand washing / washing and shaving

$\mathrm{d}_{\text {nursing homes / hotels }}$

eapacity: 1201

\subsubsection{DHW energy consumption}

3.1.1.1. DHW occupant-related method. The end-use types, volumetric flows $\dot{V}_{e}$, use frequency $f_{e}$ and duration $d_{e}$ of Blokker et al. [52] are selected for the present case-study, as the data are relatively recent and similar DHW use between the Netherlands and Luxembourg can be assumed as both countries are geographically close and have similar living standards. The end-use types retained are also those generally mentioned in DHW-related publications.

A distribution between efficient and normal shower of $50 \%$ is considered. Energy consumption related to shower, bathtub (when available) and bathroom sink use is calculated in function of inhabitant number. Kitchen sink use (hand washing and dish washing) is related to the household number in the building, as indicated by Blokker et al. [52]. A dish-washer occurrence rate of $79 \%$ is used (Statec [61]), which implies that $21 \%$ of the households are doing their dish washing by hand. The French bathtub occurrence rate of $74.4 \%$ is applied here. Dishwashers and bathtubs are geoallocated using the RANDOM function in PostgreSQL [57], as more detailed information are not available. The resulting percentage of dish-washer and bathtub occurrence in Esch reaches $78.8 \%$ for the dish washer, and $74.3 \%$ for the bathtubs. For the theoretical low energy and passive single family and multifamily building models, it is assumed that they are equipped with a dishwasher and bathtub.

For hotels and nursing homes, the DHW streams related to the rooms - shower, bathroom sink (washing and shaving) and bathtubs (when occurring) - are considered. The volumetric flows $\dot{V}_{e}$, use frequency $f_{e}$ and duration $d_{e}$ values of Blokker et al. [55] are used. A normal shower type having a volumetric flow of $0.14 \mathrm{l} / \mathrm{s}$ is considered. While in hotel five the rooms are equipped with a bathtub and hotels two and three are not, detailed information for hotel one and four are not available. An occurrence rate of $50 \%$ is therefore assumed. Eurostat [71] indicates for the Grand-Duchy of Luxembourg, in 2014 for hotels and similar accommodations, a bed-per-room number of 1.9. The number 
Table 5: DHW use durations, in $\mathrm{s}$

\begin{tabular}{|c|c|c|c|c|c|c|}
\hline Reference & $\begin{array}{l}\text { Cobacho } \\
\text { et al. [54] }\end{array}$ & $\begin{array}{c}\text { Schramek } \\
{[35]}\end{array}$ & $\begin{array}{l}\text { Blokker } \\
\text { et al. [52] }\end{array}$ & $\begin{array}{c}\text { Blokker et al. } \\
{[55]}\end{array}$ & $\begin{array}{l}\text { Neunteufel } \\
\text { et al. [45] }\end{array}$ & $\begin{array}{c}\text { Neunteufel } \\
\text { et al. [45] } \\
\text { (EU } \\
\text { values) }\end{array}$ \\
\hline $\begin{array}{l}\text { Building } \\
\text { type }\end{array}$ & Hotel & Household & Household & $\begin{array}{l}\text { Hotel, nursing } \\
\text { home }\end{array}$ & Household & Household \\
\hline $\begin{array}{l}\text { Bathroom } \\
\text { sink }\end{array}$ & - & $90 / 120^{a}$ & $40^{\mathrm{c}}$ & $16 / 40^{\mathrm{e}}$ & 59 & - \\
\hline $\begin{array}{l}\text { Kitchen } \\
\text { sink }\end{array}$ & - & 300 & $15 / 48^{d}$ & - & 59 & - \\
\hline Showering & 270 & 360 & 510 & 510 & 288 & 474 \\
\hline $\begin{array}{l}\text { Bath } \\
\text { filling }\end{array}$ & - & $900 / 1200^{b}$ & 600 & 600 & - & - \\
\hline 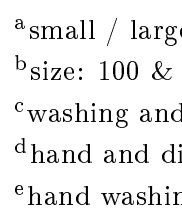 & $\begin{array}{l}\text { sink } \\
60 / 180 \\
\text { having } \\
\text { h washing } \\
\text { / washing }\end{array}$ & laving & & & & \\
\hline
\end{tabular}

of hotel customers is calculated considering a yearly average bed place occupancy of $35,1 \%$ (Eurostat [72]). The year of construction of hotel two is not given in the GIS data set, but as it is a very recent building, it is set to 2012. Nursing homes are only equipped with showers. The nursing homes are also equipped with small kitchen units, but it is not expected that the inhabitants do manual dishwashing. The number of occupants is taken from the GIS data set. The values for the various sites are summarised in tab.7.

3.1.1.2. DHW surface-related method and surface quantification. In order to compare the outcomes of the proposed DHW occupant-related model, the DHW energy consumption according to the surface is calculated. Specific energy consumption values for domestic hot water production of 13.9 and 20.8 $\mathrm{kWh} / \mathrm{m}^{2}$ a for single and multifamily buildings are assumed (Luxemburgish Parliament [83]). The latter value is also used for mixed-use buildings (MUB). For lodgings, values of $88 \mathrm{kWh} / \mathrm{m}^{2}$ for nursing homes and $153 \mathrm{kWh} / \mathrm{m}^{2}$ for hotels are used (Luxemburgish Parliament [84]).

The household floor surfaces of domestic use buildings are obtained by multiplying the footprint area, obtained from the ST_AREA function of PostGIS (PostGIS Project [81]), with the building floor number (including the attic). This method was selected as its outcomes fits best with average household surface values for Esch mentioned in national population census data (Statec [85]). The average surface of single family and multifamily buildings in Esch, $165.65 \mathrm{~m}^{2}$ and $511.72 \mathrm{~m}^{2}$ respectively, are considered too for the low energy and passive buildings. For mixed-use buildings and lodgings, this method is not specific enough, as surfaces not related to domestic use would also be included. The reference surface is therefore calculated using the average household surface, obtained from the national population survey (Statec [85]) for Esch, multiplied by the household number (tab.8).

For hotels and nursing homes, average room surfaces and room numbers are used to calculate the relevant area (tab.7). Data for hotels are obtained from tourism sites: ONT [69] for room numbers and Booking.com [86] for the calculation of average room surface. As surface data for hotel 3 are not 
Table 6: Dishwasher occurrence rates

\begin{tabular}{cccc}
\hline Country & $\begin{array}{c}\text { Occurrence } \\
{[\%]}\end{array}$ & $\begin{array}{c}\text { Year of survey } \\
{[\text { [year] }}\end{array}$ & Source [-] \\
\hline \hline Austria & 74 & 2012 & Statistik Austria [58] \\
\hline France & 56 & 2014 & INSEE [59] \\
\hline Germany & 68 & 2011 & Statistisches Bundesamt [60] \\
\hline Luxembourg & 79 & 2011 & Statec [61] \\
\hline Switzerland & 85 & 2014 & Morgenthaler et al. [62] \\
\hline
\end{tabular}

Table 7: Hotels and nursing homes data

\begin{tabular}{lcccc}
\hline Building & $\begin{array}{c}\text { Number of } \\
\text { rooms [-] }\end{array}$ & $\begin{array}{c}\text { Daily cus- } \\
\text { tomer/patients }\end{array}$ & $\begin{array}{c}\text { Bathtub } \\
\text { number } \\
{[-]}\end{array}$ & $\begin{array}{c}\text { Average room } \\
\text { surface }\left[\mathrm{m}^{2}\right]\end{array}$ \\
\hline \hline Hotel 1 & 23 & 15.34 & 12 & 18.3 \\
\hline Hotel 2 & 110 & 73.36 & 0 & 18.0 \\
\hline Hotel 3 & 22 & 14.67 & 0 & $18.3^{*}$ \\
\hline Hotel 4 & 15 & 10.00 & 15 & 35.0 \\
\hline Hotel 5 & 20 & 13.34 & 10 & 27.8 \\
\hline Nursing home 1 & 168 & 157.00 & 0 & 30.5 \\
\hline Nursing home 2 & 46 & 32.00 & 0 & $30.5^{*}$ \\
\hline$*$ assumption & & & &
\end{tabular}

available, the value of hotel 1 is assumed, because both hotels are similar in size and type. Values between 22 to $32 \mathrm{~m}^{2}$ for 114 rooms and 34 to $42 \mathrm{~m}^{2}$ for 54 rooms are mentioned for nursing home 1 (Servior [87]), leading to an average room surface of $30.5 \mathrm{~m}^{2}$. This value is equally used for nursing home 2, as no further data are available. The number of rooms for this type of building is taken from the GIS data set of the municipality.

\subsubsection{Total heat demand using linear regression}

A multiple linear regression model is developed to estimate the energy consumption of residential buildings based on measured consumption data. Household budget survey data are obtained from the national statistic agency STATEC (Statec [82]). The model is implemented in the software R (R Core Team [88]) and fitted using the Ordinary Least Squares (OLS) method.

Data from the year 2011 are selected to fit the model due to meteorological condition similar to the average of the region. Only dwellings having natural gas or fuel oil as main fuel are selected. The energy consumption in $\mathrm{kWh} / \mathrm{a}$ is obtained by multiplying the amount of fuel consumed $\left(\mathrm{m}^{3}\right.$ of gas and litres of oil) by suitable calorific values. A distribution of heating systems (traditional and condensing) is assumed based on statistical data to obtain an average calorific value based on national values (Luxemburgish Parliament [83]).

The final sample of observations used to fit the model consists of 794 records (of a total of 1'142) and is obtained by excluding the following items from the original data set: records with missing 
Table 8: Average household surface for mixed-use buildings in Esch (Statec [85])

\begin{tabular}{|c|c|c|c|}
\hline $\begin{array}{c}\text { Building type, Statec } \\
\text { typology }\end{array}$ & $\begin{array}{l}\text { Building type, GIS } \\
\text { typology }\end{array}$ & $\begin{array}{l}\text { Number of } \\
\text { households per } \\
\text { building }\end{array}$ & $\begin{array}{c}\text { Average } \\
\text { surface }\left[\mathrm{m}^{2}\right]\end{array}$ \\
\hline \multirow{3}{*}{$\begin{array}{l}\text { Collective building, } \\
\text { mixed usage }\end{array}$} & \multirow{3}{*}{ Building, mixed usage } & 1 & 136.55 \\
\hline & & $2-4$ & 66.59 \\
\hline & & $>4$ & 75.52 \\
\hline \multirow{3}{*}{ Home for adults } & \multirow{3}{*}{ Hosting structure } & 1 & 74.875 \\
\hline & & $2-4$ & 25 \\
\hline & & $>4$ & 85 \\
\hline \multirow{3}{*}{$\begin{array}{l}\text { Collective building, for } \\
\text { living purpose }\end{array}$} & \multirow{3}{*}{ Student home } & 1 & 108.71 \\
\hline & & $2-4$ & 79.67 \\
\hline & & $>4$ & 71.81 \\
\hline \multirow{3}{*}{ Other dwelling } & \multirow{3}{*}{$\begin{array}{l}\text { Public usage, } \\
\text { manufacturing industry } \\
\text { building, commerce or } \\
\text { service industry }\end{array}$} & 1 & 93.33 \\
\hline & & $2-4$ & 64.8 \\
\hline & & $>4$ & 54.125 \\
\hline
\end{tabular}

values; use of other fuels than gas and oil; presence of solar panels; not realistic ratio between energy expenditure and energy consumption, index of errors in the compilation of the survey.

The formulation of the outcome of the linear regression analysis is given by the following equation:

$$
\ln (y)=\beta_{0}+\ln \left(x_{\text {floor }}\right) \cdot \beta_{\text {floor }}+\ln \left(x_{\text {occ }}\right) \cdot \beta_{\text {occ }}+x_{\text {type }} \cdot \beta_{\text {type }}+\sum_{i=1}^{5}\left(x_{\text {period }, i} \cdot \beta_{\text {period }, i}\right)+\varepsilon
$$

where $y$ represents the energy consumption of the dwelling in $\mathrm{kWh} / \mathrm{a}, x_{\text {floor }}$ the useful floor surface in $\mathrm{m}^{2}, x_{o c c}$ the number of occupants, $x_{\text {type }}$ the type of building (single family building $=1$, multifamily building $=0$ ), $x_{\text {period, } i}$ the construction period of buildings (factorial variables) and $\varepsilon$ the random error term. Some of the variables are logarithmically transformed as they present right skewness and other authors showed how this transformation can substantially improve the performance of the method (Kolter and Ferreira [89]).

Results of multiple linear regression are reported in tab.9. The coefficient of determination $R^{2}$ shows that $54.1 \%$ of the variance is taken into account by the model and it is comparable with the ones obtained by similar studies (Guerra Santin et al. [29]). The model assumptions were carefully verified and not significant heteroskedasticity and multi-collinearity problems were detected. The equation for multifamily buildings is also applied to mixed-use buildings.

\subsubsection{Space heating energy consumption}

The space heating energy consumption is calculated by subtracting the DHW energy consumption (section 3.1.1.1) from the total heat consumption (section 3.1.2), considering an utility efficiency $\eta_{u t i l i t y}$ of $90 \%$. For low energy and passive single family and multifamily buildings, specific SH values of $43 / 22 \mathrm{kWh} / \mathrm{m}^{2}$ and $27 / 14 \mathrm{kWh} / \mathrm{m}^{2}$ are used (Luxemburgish Parliament [83]). As the equations are 
Table 9: Statistical summary of the multiple linear regression for residential buildings

\begin{tabular}{|c|c|c|c|c|c|}
\hline Coefficients & Estimate & Std. Error & $\mathrm{t}$ value & Significance & \\
\hline Intercept & 6.809 & 0.206 & 33.080 & $<0.0001$ & $* * *$ \\
\hline Floor surface $(\ln )$ & 0.568 & 0.047 & 12.074 & $<0.0001$ & $* * *$ \\
\hline Number of occupants $(\ln )$ & 0.106 & 0.030 & 3.555 & 0.0004 & $* * *$ \\
\hline Type 1: single family house & 0.297 & 0.044 & 6.675 & $<0.0001$ & $* * *$ \\
\hline Period 1: <1919 & 0.220 & 0.068 & 3.235 & 0.00127 & $* *$ \\
\hline Period 2: 1919-45 & 0.148 & 0.054 & 2.768 & 0.0058 & $* *$ \\
\hline Period 3: 1946-60 & 0.159 & 0.048 & 3.278 & 0.0011 & $* *$ \\
\hline Period 4: 1961-80 & 0.204 & 0.041 & 4.979 & $<0.0001$ & $* * *$ \\
\hline Period 5: 1981-95 & 0.149 & 0.044 & 3.388 & 0.0007 & $* * *$ \\
\hline \multicolumn{6}{|c|}{$\begin{array}{l}\text { Signific. codes: } * * *<0.001, * *<0.01, *<0.05, .<0.1, \mathrm{R}^{2}=0.541, \text { Adjusted } \mathrm{R}^{2}=0.536 \\
\text { Residual standard error: } 0.404 \text { on } 785 \text { degrees of freedom, } p-\text { value }<2.2 \cdot 10^{-16} \\
\text { Notes: Variables "T2: Multi-family house" and "P6: }>1995 \text { " assumed as reference. } \\
\text { Coefficients marked with }\end{array}$} \\
\hline
\end{tabular}

not applicable to hotels or nursing homes due to difference in user behaviour, the total and space heating energy consumption is only calculated for domestic buildings.

\subsubsection{Heat exchanger load for district heating systems}

The SH load of domestic buildings is calculated using the heating signature calculation (Girardin et al. [21]). The 2011 outdoor temperature $T_{\text {outdoor }}$ behaviour in function of time $t$, based on data from the air transport service in Luxembourg (Administration de la navigation aérienne [90]), is modelled using polynomial regression analysis (eq.14). The coefficient of determination $R^{2}$ reaches $64 \%$.

$$
T_{\text {outdoor }}=2 E-17 t^{5}-4 E-13 t^{4}+3 E-09 t^{3}-8 E-06 t^{2}+0,0003 t+16,771
$$

A minimum outdoor temperature of $-10^{\circ} \mathrm{C}$ and a threshold temperature of $15^{\circ} \mathrm{C}$ are considered. Eq.14 is integrated between the time intervals of 550 and 5'940 hours, where the outdoor temperature is below and above $15^{\circ} \mathrm{C}$, respectively. The space heating load of each building is finally obtained by multiplying its reference area with the specific SH load obtained from the heating signature.

With the selected DHW household streams, three types of end-uses are to be considered for the maximal DHW load: dish washing, bathtub or shower. The determination of the relevant end-use depends of the occurrence of dish-washer and bathtub in the household. In case a dish-washer is not installed, a maximum DHW load of $30.10 \mathrm{~kW}$ is considered. Else, if a bathtub is available, a load of $25.08 \mathrm{~kW}$ is retained. Finally, if both end-uses are not available, the load of the shower is prevailing with $16.30 \mathrm{~kW}$. Following eq. 8 as well as eq.9 or eq.10 for households and multifamily buildings, respectively, the load of stand-alone heat exchangers is finally obtained.

In order to compare the results, eq.7 is applied to calculate the load of an utility combined with a hot water storage system.

\subsubsection{Energy integration of decentralised heat pump considering various hot water temperature levels}

Former works on integrated urban energy optimisation have so far modelled DHW demand as hot water stream at $60^{\circ} \mathrm{C}$ (Perry et al. [20], Weber [23], Girardin et al. [21], Varbanov et al. [91], Fazlollahi 
et al. [92]). However, as stated by Girardin et al. [21], various heating utilities providing heat at close space heating and domestic hot water temperatures, like heat pumps and low-grade waste heat recovery, are particularly sensitive to temperature level requirements. Therefore, the impact of the proposed DHW models on the integration of heat pump as heating utility is assessed as example, using the energy integration approach described by Weber [23].

The above-mentioned low energy single family building, equipped with bathtub and dishwasher, is selected as low-temperature SH case study. The space heating load of the building is calculated using the heating signature for the coldest day of the year, with a floor heating system with supply and return temperatures of $30 / 25^{\circ} \mathrm{C}$ (Hesaraki et al. [93]). For the first case, a hot water production at $60^{\circ} \mathrm{C}$ in the storage tank is considered, the load being calculated by dividing the annual DHW energy consumption by 8670 hours. In the second case, a temperature of $50^{\circ} \mathrm{C}$ is used, as it has been showed that for new or renovated buildings with DHW system volumes below 3 litres and individual DHW feeding pipes, this level is sufficient to avoid Legionella proliferation (Brand et al. [19]). The temperature difference between the condensing side of the heat pump and the hot water is maximum $5 \mathrm{~K}$. The evaporation side has a temperature of $5^{\circ} \mathrm{C}\left(5 \mathrm{~K}\right.$ below the average of $10^{\circ} \mathrm{C}$ outdoor temperature), and the electricity consumption is calculated considering a Carnot factor of $55 \%$ (Becker et al. [94]). Finally, a price of $0.141 € / \mathrm{kWh}$ is used to calculate the operating costs (Enovos [95]).

\subsection{Results}

As measured DHW energy consumption data are not available to validate the proposed methodology, the results obtained are compared, in section 3.2.1, to typical values indicated in the literature. In section 3.2.2 and 3.2.3, the DHW-related energy demand is assessed as to the main end-uses and temperature levels. The heat exchanger loads, considered with and without hot water storage, are displayed at district level in section 3.2.4. Finally, the outcomes of the energy integration of heat pumps at different hot water temperatures are presented in section 3.2.5.

\subsubsection{Validation of outcomes with literature values}

The total yearly heat demand of the households in Esch amounts to 189.2 GWh (fig.2 and fig.3).

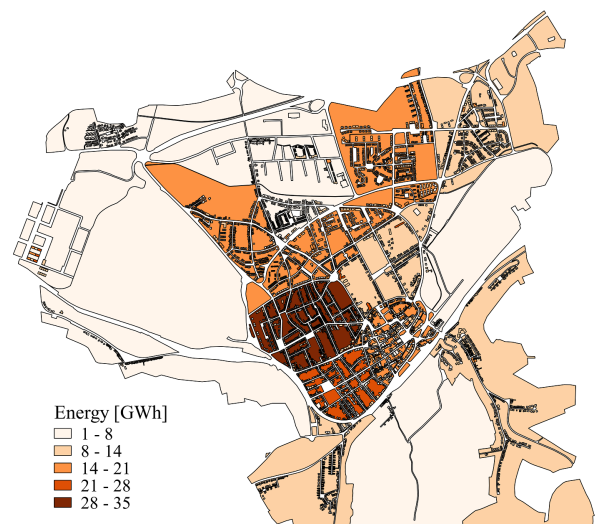

Figure 2: Total household yearly heat consumption at district level

The household DHW energy demand of the proposed methodology is, at city level, $15 \%$ lower than that of the surface-related model (fig.3). Districts 5, 13 and 16 have particularly high negative differences, with $45-52 \%$ less energy demand. On the other hand, districts 2 and 12 show the opposite behaviour, with the proposed methodology generating energy use values $14-22 \%$ higher than the surface-related method. These difference are due to the reference surface. As represented with the 
light blue bars, the higher the surface per inhabitant, the higher the difference between the two DHW models. In case the average surface per inhabitant is particularly low, the occupant-related method obtains higher energy consumption values than the surface-related model.

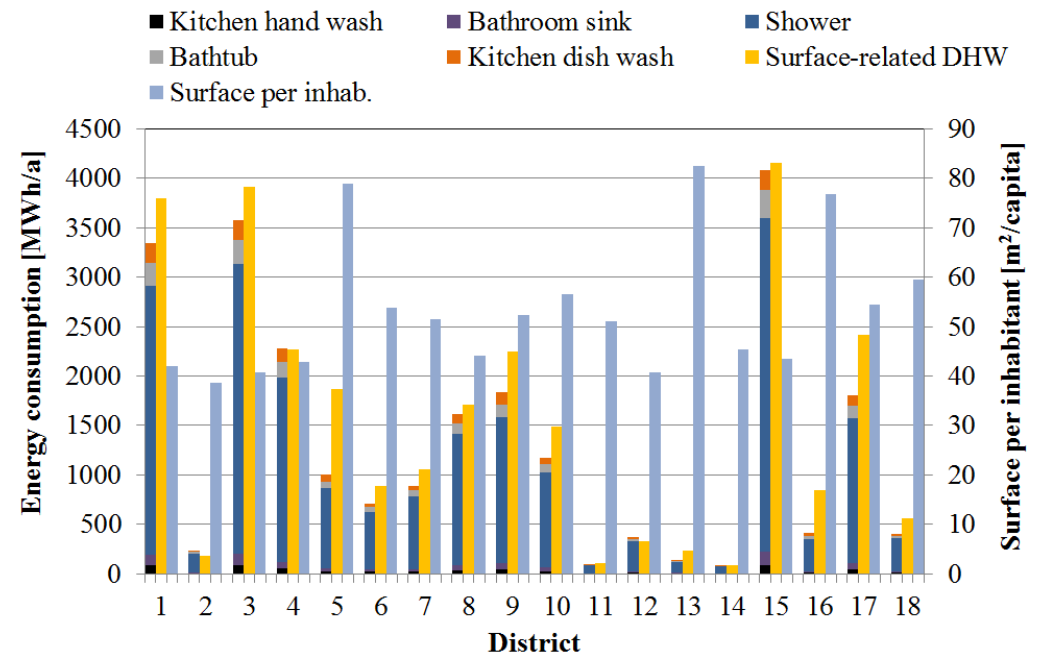

Figure 3: DHW-related energy demand and surface per inhabitant (blue column) of households at district level

Concerning the hotels and nursing homes, the difference between the two methods is even more important, with the detailed modelling method reaching only $20 \%$ and $9 \%$ of the surface-related energy consumption, respectively (fig.4). Part of this difference can be explained by the fact that the specific DHW energy consumption values are generic and might include additional streams (e.g. room cleaning, bathtub) that are not considered with the proposed model. In addition, an occupancy rate of $35.1 \%$ is considered for the hotels, while the surface-related approach assumes an occupancy rate of $100 \%$ of the surface.

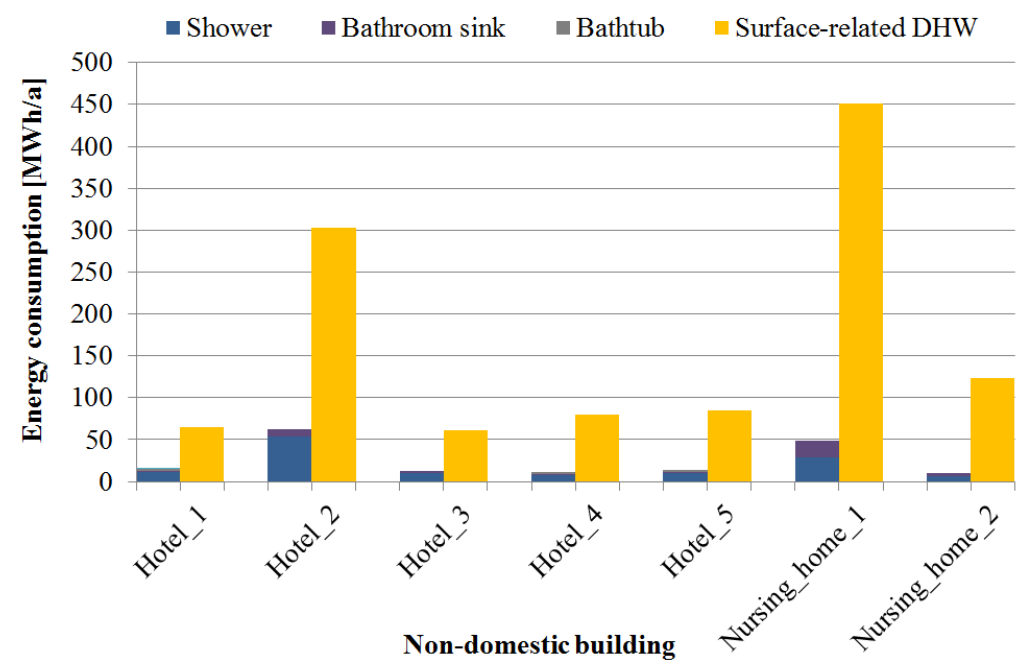

Figure 4: DHW energy demand of lodgings

Considering a hot water temperature of $60^{\circ} \mathrm{C}$, a hot water consumption of $33.4 \mathrm{l} /$ capita*day is ob- 
tained using the proposed DHW models. Maas et al. [96], Schramek [35] and Girardin et al. [21] mention values of 40 l/capita*day (Luxembourg), 30-60 l/capita*day (Germany) and 50-70 l/capita*day (Switzerland), respectively.

Single family (SFB in fig.5), multifamily (MFB) and mixed-use (MUB) buildings have a specific energy demand between $124-172 \mathrm{kWh} / \mathrm{m}^{2}, 60-122 \mathrm{kWh} / \mathrm{m}^{2}$ and $80-123 \mathrm{kWh} / \mathrm{m}^{2}$, respectively. The outcomes for single family buildings build after 1995 confirms the findings of Maas et al. [96], who obtained an average energy consumption of $131 \mathrm{kWh} / \mathrm{m}^{2}$ over a sample of 54 buildings built between 1997 and 2007. However, the generated values are lower than those measured by Merzkirch et al. [97], who mentions values of $170 \mathrm{kWh} / \mathrm{m}^{2}$ and $120 \mathrm{kWh} / \mathrm{m}^{2}$ for single and multifamily buildings built after 1994 on. This difference is most probably due to the uncertainties of the regression analysis results.

Fuel consumption for heating is, as expected, mostly related to space heating (fig.5), and decreases for more recent buildings. Concerning existing single family buildings, the fuel conversion losses of the heating utility are higher than the fuel consumption related to DHW. For multifamily and mixed-use buildings, DHW fuel consumption is almost twice as high than the utility losses.

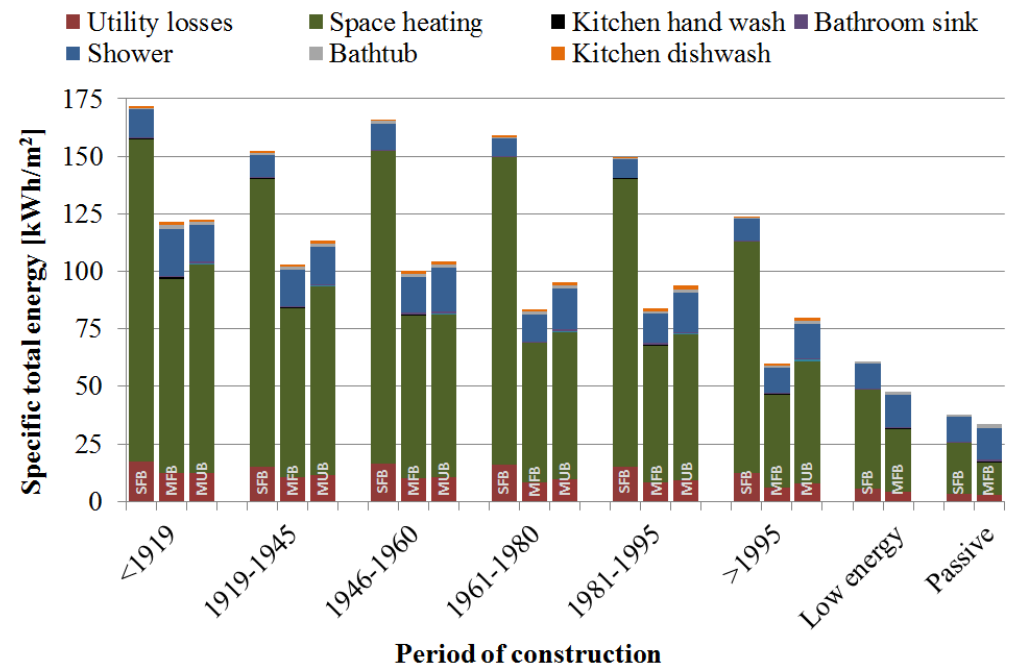

Figure 5: Specific thermal energy demand of households (SFB - single family building, MFB - multifamily building, MUB: mixed-use building)

The contribution of the DHW streams to the total heat demand (including utility losses), amounts at city level to $17.6 \%$, while it varies between 6-9\% (single family building), 17-23\% (multifamily building) and 16-24\% (mixed-use) for the considered periods of construction (fig.6). The order of magnitude of these results is confirmed by literature values (Enerdata [4]: 15.9\%, Frijns et al. [5]: $20.3 \%$, Tooke et al. [98]: 22\%). The relevance of DHW energy consumption is $20 \%$ and $33 \%$ for low-energy and passive SFB and $34 \%$ and $49 \%$ for MFB. Esch single family and multifamily buildings (mixed usage buildings included) have a specific DHW energy consumption of $11.75 \mathrm{kWh} / \mathrm{m}^{2}$ and $17.33 \mathrm{kWh} / \mathrm{m}^{2}$, while values of $13.9 \mathrm{kWh} / \mathrm{m}^{2}$ and $20.8 \mathrm{kWh} / \mathrm{m}^{2}$ are at national level (Luxemburgish Parliament [83]).

\subsubsection{Contribution of DHW streams to household energy consumption}

In terms of energy consumption, showering represents by far the most relevant DHW stream, which is confirmed by Elias-Maxil et al. [17], contributing between 5-8\% (SFB), 14-18\% (MFB) and 13-19\% (MUB) to the total heat consumption of the buildings (fig.6). For low energy and passive buildings, this value reaches between 20 and $30 \%$ for single family and between 30 and $44 \%$ for multifamily 


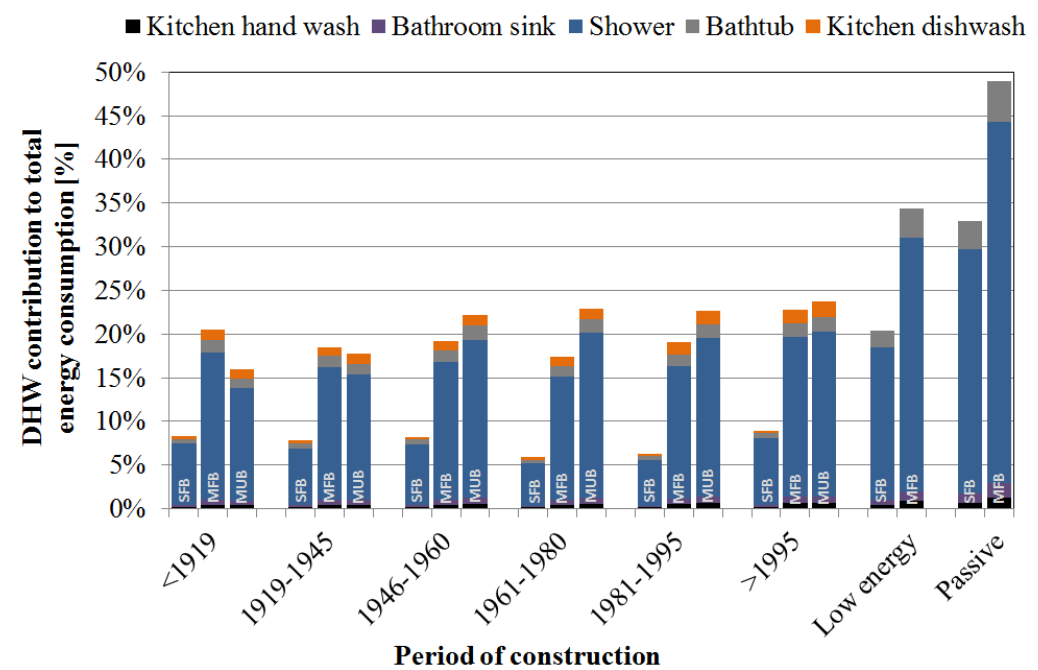

Figure 6: DHW energy demand contribution in households (SFB - single family building, MFB - multifamily building, MUB: mixed-use building)

buildings. The bathtub makes up between 2 to $5 \%$ of the total heat consumption, and the other streams around $1 \%$.

Related to the total DHW energy consumption, showers contribute between 80 and $84 \%$ (fig.7). The energy consumption of the other DHW streams is comparatively small, with the bathtub contributing to $7 \%$, the dish washing between 3 to $7 \%$, the bathroom sink to $3 \%$ and hand washing to 2 to $3 \%$. In low energy and passive buildings, shower makes up to $85 \%$ of the DHW energy consumption, bathtub $10 \%$, with the remaining streams totalling $5 \%$.

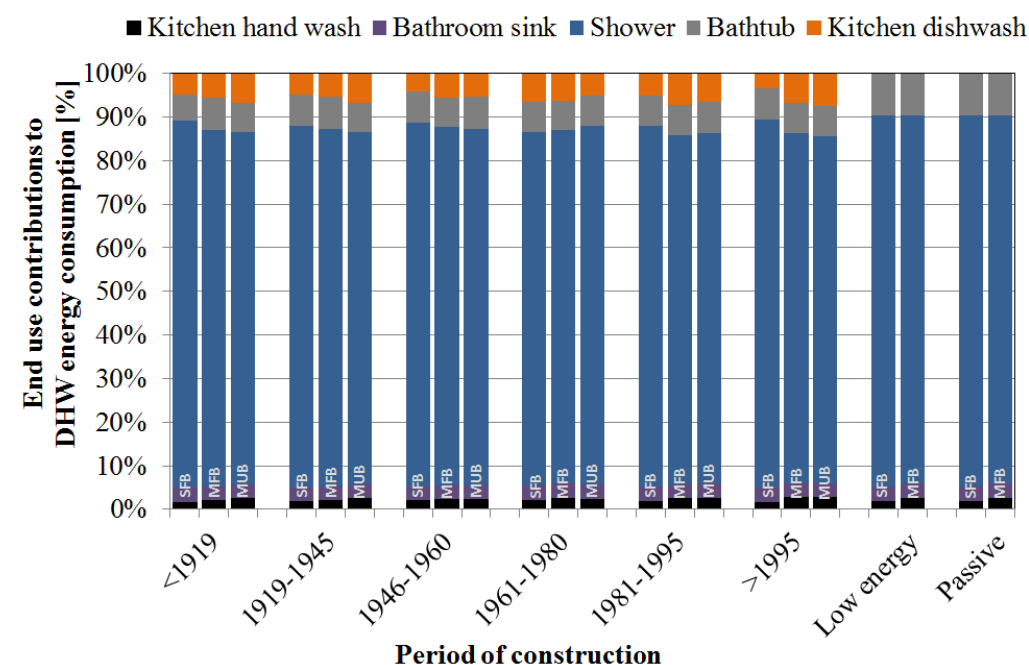

Figure 7: End-use contribution to household DHW energy demand (SFB - single family building, MFB - multifamily building, MUB: mixed-use building) 


\subsubsection{DHW temperature level requirements}

Considering temperature levels, $0-1 \%$ of the total heat consumption is used for domestic hot water use at $35^{\circ} \mathrm{C}$ (all types of buildings), while $40^{\circ} \mathrm{C}$ streams represent $5-8 \%, 15-20 \%$ and $14-21 \%$ of the heat consumption of single family, multifamily and mixed-use buildings. DHW demand at $55^{\circ} \mathrm{C}$ (dish washing) lies between $0-2 \%$ of the total household heat consumption. For low energy and passive buildings equipped with dishwashers, $1-3 \%$ of the DHW energy consumption is related to $35^{\circ} \mathrm{C}$ streams, while 19 to $46 \%$ of the energy consumption is for $40^{\circ} \mathrm{C}$ domestic hot water.

Set in relation to the DHW energy consumption, dish washing at $55^{\circ} \mathrm{C}$ makes between 5 to $7 \%$ of the energy use (fig.8). 93\% of the DHW energy consumption is therefore related to streams at or below $40^{\circ} \mathrm{C}$, with $35^{\circ} \mathrm{C}$ end-use streams (hand wash and washing and shaving) representing around $5 \%$. In low energy and passive buildings, $35^{\circ} \mathrm{C}$ streams amounts to approximately $6 \%$ of DHW energy consumption, while, with the assumption that dishwasher are installed and therefore no $55^{\circ} \mathrm{C}$ hot water is required, the rest is used for $40^{\circ} \mathrm{C}$ streams.

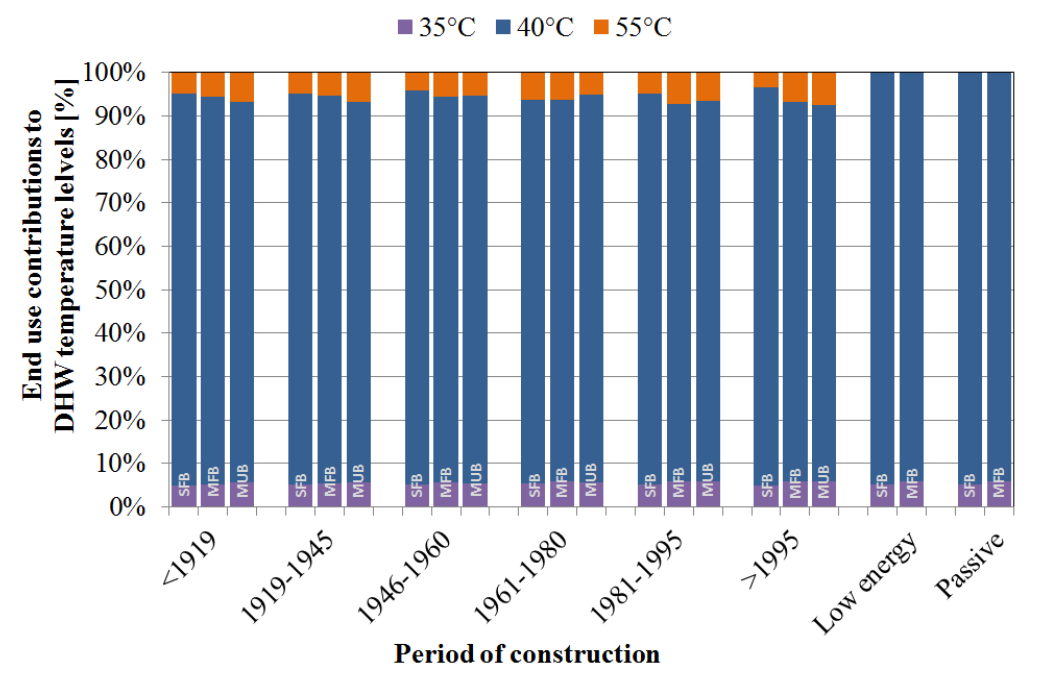

Figure 8: Temperature level contribution to household DHW energy demand (SFB - single family building, MFB multifamily building, MUB: mixed-use building)

\subsubsection{Heat exchanger load for district heating systems}

With the characterisation of the various DHW streams, the load of DH stand-alone heat exchangers of $99 \%$ of the single family and $100 \%$ of the multifamily and mixed-use buildings is designed according to the DHW demand. Due to the high occurrence of dishwashers and bathtubs, $59 \%$ of the utility load of households are sized according to the bathtub load requirement. The stand-alone heat exchanger load of buildings, aggregated at district level (fig.9a), is between 1.9 and 2.9 times higher compared to a configuration with a hot water storage system (fig.9b).

\subsubsection{Energy integration of decentralised heat pump considering various hot water temperature levels}

The results of the energy integration of the heat pump in the low energy single family building is represented as cold (blue line) and hot (red line) composite curves, with the former representing the heating requirements of the building, and the latter the heat pump heating load. As the curves are based on pinch analysis theory (Linnhoff et al. [99]), they are both shifted by half of the assumed 


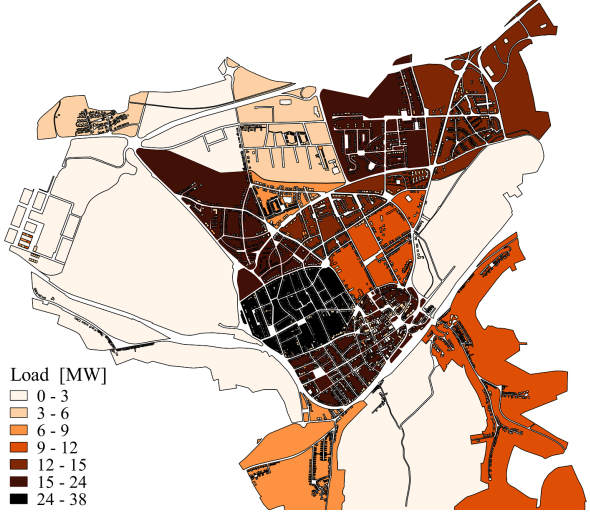

(a) Stand-alone heat exchanger

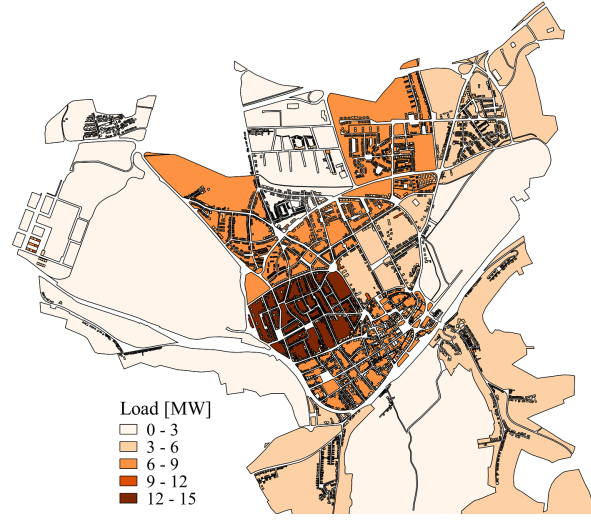

(b) Heat exchanger with hot water storage

Figure 9: Utility heating load at district level

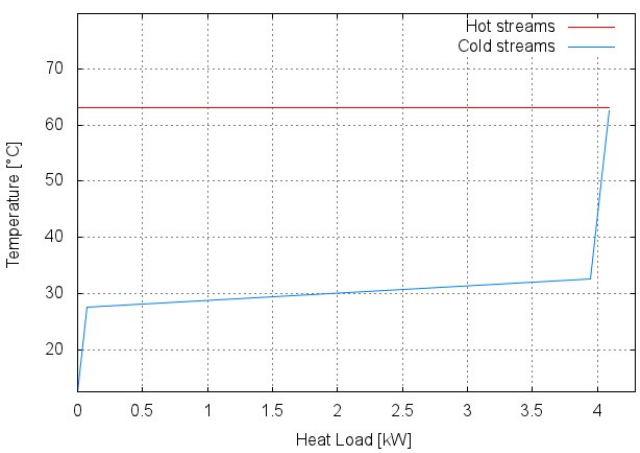

(a) Hot water at $60^{\circ} \mathrm{C}$ $359 € /$ year.

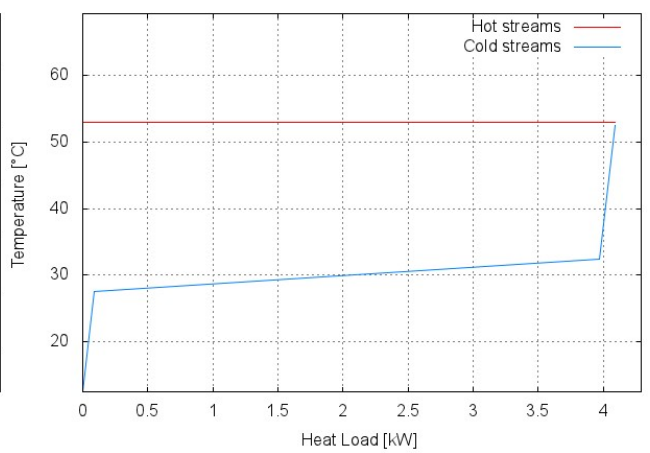

(b) Hot water at $50^{\circ} \mathrm{C}$

Figure 10: Composite curves of a low energy, single family building

minimum temperature difference of $5 \mathrm{~K}$, which explains e.g. the heating requirements temperature of

fig.10a represents the configuration with $60^{\circ} \mathrm{C}$ hot water production. Considering an evaporation temperature of $10^{\circ} \mathrm{C}$, the heat pump has a temperature lift of $50 \mathrm{~K}$, which leads to a Coefficient Of Power (COP) of 3.10 and electricity costs of $419 € /$ year. By reducing the hot water temperature level (fig.10b) to the minimum required by space heating, DHW end-use temperature levels and hygienic constraints, the COP of the heat pump is increased by $14 \%$ to a value of 3.61 , reducing the costs to

\section{Discussion}

Although measured data on DHW energy consumption are not available to validate the outcomes of the case study and, therefore, the proposed modelling method, the related energy demand results are nevertheless confirmed by previous works focusing on DHW urban energy consumption. 
The lower DHW energy consumption values of the proposed method, compared to the surfacerelated method, and the lower specific energy consumption per surface, compared to legislation values, actually highlight an advantage of the exposed method. The observed differences of the case-study are most probably due to the inaccuracies in surface estimations, generated with geographical data and therefore including non-heated surfaces (e.g. garages) or actually non-existing areas for buildings with different levels. As an alternative to these estimation, the proposed modelling approach instead relies on occupant and household or room numbers, data that are usually available from the municipality or other sources. In addition, as particularly highlighted in the case of hotels in section 3.2.1, using building occupant number instead of surface data as input parameter also allows to reflect the actual level of occupancy of a building. An allocation of DHW energy use to empty or less-occupied buildings is therefore avoided. By relating the DHW consumption to the occupants, the proposed method generates more accurate results, in particular when surface data can only be roughly estimated. The outcomes of space heating energy demand, when calculated at district, street or building block levels, is therefore more precise. Due to the use of a randomising function for the geoallocation of various end-uses, the proposed method should not be applied at building level. However, this is actually not an issue, as the specific characterisation of the actual DHW end-uses can then be addressed in detail anyway.

One drawback of the proposed DHW modelling method is the limited input data availability. DHW data specific to the country should be considered, as water use differs according to geographical location and living standards. But information on volumetric or mass flow, use duration, use frequency and end-use occurrence are generally scarce, in particular for non-domestic buildings. Specific data for other types of buildings with relevant DHW demand (e.g. hospitals, sport facilities) are not even available or sufficiently detailed out. An additional weak point is the use of national statistical values to calculate unit occupancy of lodgings, as an equal distribution of customers across the country is assumed. Moreover, the detailed modelling of the DHW streams implies the risk that some end-uses might be neglected, thus distorting the DHW and SH energy demand outcomes. Finally, the actual user water consumption behaviour, which differs according to age and occupation during the day (Blokker et al. [52]), is not reflected, as this work focuses on yearly assessments.

Further DHW data, covering additional building types, are therefore necessary for a complete application of the proposed modelling method. It is also proposed to include regional or city-level information on hotels and nursing homes directly in the input data set. To avoid the risk of omitting relevant streams, users are encouraged to at least consider the four end-uses described in section 2.2, which are commonly referred to in DHW-related publications. A validation of the aggregated DHW demand results with national values is also recommended. Daily user behaviour patterns have already been addressed in former publications and can be referred to in order to conduct assessments with smaller time scale. Globally, as household DHW energy consumption is due to more than $80 \%$ to showering only, integrated urban energy assessments and optimisation shall particularly focus on the characterisation on this specific end-use.

The main significance of the proposed DHW modelling method lies in the simultaneous differentiation and temperature characterisation of various DHW streams at urban scale, which leads to three main contributions to current integrated urban energy assessments and optimisation methods.

First, the various heating demands of urban systems are better differentiated. This allows to address the impact of specific optimisation measures, like water saving techniques or in-shower, inbuilding or in-sewer heat recovery solutions. Moreover, the proposed method already generates part of the necessary DHW data (stream types, flows, temperature, etc.) for the modelling and integration of these optimisation measures at urban scale.

Second, the technological scope of integrated energy optimisation of heating utilities in buildings with low temperature space heating is increased. The utility temperature of this type of building is defined by the DHW requirements, as space heating temperature lies below that of DHW end-uses 
(Brand et al. [19]). These requirements are precisely characterised with the use of the proposed DHW modelling method, the only limit remaining Legionella proliferation, which, under certain DHW system configurations, can still be avoided with hot water production temperature below $50^{\circ} \mathrm{C}$. Therefore, with the decrease of the temperature level requirement from typical $60^{\circ} \mathrm{C}$ to below $50^{\circ} \mathrm{C}$, low temperature utilities, like heat pumps or low temperature waste heat, have a stronger impact in the integrated selection of optimal heating utilities. The reduction in temperature lift profits heat pumping solutions, as their efficiency is improved with lower condensing temperature, and waste heat at a low temperature level can be further valorised as the demand of fitting low temperature heat users is better characterised.

Finally, with the characterisation of the main DHW end-use loads, an additional configuration for district heating transfer stations is available for integrated energy optimisation of urban systems. The characterisation of these loads allows to model stand-alone heat exchangers, an alternative to the heat exchanger and hot water storage unit configuration considered so far in integrated energy optimisation. Previous works have showed that these stand-alone systems can yield equivalent or even better costs and energy efficiency results. The optimal selection between these two configurations should therefore be addressed in future integrated urban energy optimisation works.

\section{Conclusions}

A specific method characterising the main domestic hot water appliances in households, hotels and nursing homes at urban level has been presented. The DHW-related energy demand results have been confirmed by typical values in a real case-study. The proposed method contributes to urban energy assessment methods by detailing out the type and quantity of energy demand of various building heating end-uses, therefore providing part of the necessary data to address hot water energy saving measures. The DHW models also contribute to the improvement of integrated urban energy optimisation, in particular of buildings with low temperature space heating, by providing specific data on temperature level requirements. As these temperatures are lower than those currently assumed, systems like heat pumps and low temperature waste heat see their efficiency improved. Finally, the method contributes to the integrated design and optimisation of district heating networks with the modelling of an additional configuration of heat exchangers without hot water storage unit, which can in certain cases have lower costs and / or better energy efficiency than configurations with storage tanks.

The present work therefore globally supports the energy efficiency targets set by the European Commission on the topic of near-zero energy buildings. It will be followed by the modelling of residential waste water streams and the integrated assessment of waste water heat recovery and optimal utility selection in buildings at urban scale.

\section{Acknowledgements}

This work is supported by the Luxembourgish National Research Fund, grant agreements AFR "OptiHeat" and "DAEDALUS". The authors would like to thank the municipality of Esch-sur-Alzette, the energy provider Sudstroum and the national statistic agency Statec for their support concerning the case-study.

\section{Bibliography}

[1] E. Commission, Energy Efficiency and its contribution to energy security and the 2030 Framework for climate and energy policy - $\operatorname{COM}(2014) 520$ final, URL http://ec .europa.eu/energy/ efficiency/events/doc/2014_eec_communication_adopted.pdf, 2014. 
[2] UN Habitat, Cities and climate change initiative - launch and conference report, URL http: //mirror. unhabitat.org/downloads/docs/6520_35892_0SL0\%20Report.pdf, last accessed: $12 / 11 / 2015,2009$.

[3] European Parliament, Directive 2010/31/EU of the European Parliament and of the Council of 19 May 2010 on the energy performance of buildings, 2010.

[4] Enerdata, ODYSSEE database on energy efficiency data \& indicators, URL http: //www.indicators.odyssee-mure.eu/energy-efficiency-database.html, last accessed: 24/02/2015, 2015.

[5] J. Frijns, J. Hofman, M. Nederlof, The potential of (waste)water as energy carrier, Energy Conversion and Management 65 (2013) 357 - 363, ISSN 0196-8904, doi: bibinfo\{doi\}\{http:// dx.doi.org/10.1016/j.enconman.2012.08.023\}, URL http://www.sciencedirect.com/science/ article/pii/S0196890412003512, global Conference on Renewable energy and Energy Efficiency for Desert Regions 20112011.

[6] M. Jennings, D. Fisk, N. Shah, Modelling and optimization of retrofitting residential energy systems at the urban scale, Energy 64 (2014) 220 - 233, ISSN 0360-5442, doi: bibinfo\{doi\}\{http: //dx.doi.org/10.1016/j.energy.2013.10.076\}, URL http://www.sciencedirect.com/science/ article/pii/S0360544213009432.

[7] J. A. Fonseca, A. Schlueter, Integrated model for characterization of spatiotemporal building energy consumption patterns in neighborhoods and city districts, Applied Energy 142 (0) (2015) 247 - 265, ISSN 0306-2619, doi: \bibinfo \{doi\} \{http://dx.doi.org/10.1016/j.apenergy.2014.12.068\}, URL http://www.sciencedirect.com/science/article/pii/S0306261914013257.

[8] R. Nouvel, A. Mastrucci, U. Leopold, O. Baume, V. Coors, U. Eicker, Combining GIS-based statistical and engineering urban heat consumption models: Towards a new framework for multiscale policy support, Energy and Buildings (2015) -ISSN 0378-7788, doi: bibinfo\{doi $\}$ http: //dx.doi.org/10.1016/j.enbuild.2015.08.021\}, URL http://www.sciencedirect.com/science/ article/pii/S0378778815302061.

[9] R. Yao, K. Steemers, A method of formulating energy load profile for domestic buildings in the \{UK\}, Energy and Buildings 37 (6) (2005) 663 - 671, ISSN 0378-7788, doi: \bibinfo\{doi\}\{http: //dx.doi.org/10.1016/j.enbuild.2004.09.007\}, URL http://www.sciencedirect.com/science/ article/pii/S037877880400307X.

[10] M. Aydinalp, V. I. Ugursal, A. S. Fung, Modeling of the space and domestic hot-water heating energy-consumption in the residential sector using neural networks, Applied Energy 79 (2) (2004) 159 - 178, ISSN 0306-2619, doi:〈bibinfo\{doi\}\{http://dx.doi.org/10.1016/j.apenergy.2003.12.006\}, URL http://www.sciencedirect.com/science/article/pii/S0306261903002344.

[11] J. Widen, M. Lundh, I. Vassileva, E. Dahlquist, K. Ellegard, E. Wackelgard, Constructing load profiles for household electricity and hot water from time-use data - Modelling approach and validation, Energy and Buildings 41 (7) (2009) 753 - 768, ISSN 0378-7788, doi: \bibinfo\{doi\}\{http: //dx.doi.org/10.1016/j.enbuild.2009.02.013\}, URL http://www.sciencedirect.com/science/ article/pii/S0378778809000413.

[12] C. D. Beal, E. Bertone, R. A. Stewart, Evaluating the energy and carbon reductions resulting from resource-efficient household stock, Energy and Buildings 55 (2012) 422 - 432, ISSN 0378-7788, doi: \bibinfo\{doi\}\{http://dx.doi.org/10.1016/j.enbuild.2012.08.004\}, URL http: //www.sciencedirect.com/science/article/pii/S0378778812003908, cool Roofs, Cool Pavements, Cool Cities, and Cool World. 
[13] F. Schmid, Interesting heat source for heat pumps and chillers, SwissEnergy Agency for Infrastructure Plants URL http://www.infrawatt.ch/sites/default/files/2008_Energie\% $20 \mathrm{in} \% 20$ Infrastrukturanlagen_Sewage $\% 2$ Water $\% 20$ Interesting $\% 20$ heat $\% 20$ source $\% 20$ for $\%$ 20 heat $\% 20$ pumps $\% 20$ and $\% 20$ chillers_0.pdf.

[14] A. McNabola, K. Shields, Efficient drain water heat recovery in horizontal domestic shower drains, Energy and Buildings 59 (2013) 44 - 49, ISSN 0378-7788, doi: bibinfo\{doi\}\{http://dx.doi.org/ 10.1016/j.enbuild.2012.12.026\}, URL http://www.sciencedirect.com/science/article/pii/ S0378778812006755.

[15] J. Dong, Z. Zhang, Y. Yao, Y. Jiang, B. Lei, Experimental performance evaluation of a novel heat pump water heater assisted with shower drain water, Applied Energy 154 (2015) 842 850, ISSN 0306-2619, doi: \bibinfo\{doi\}\{http://dx.doi.org/10.1016/j.apenergy.2015.05.044\}, URL http://www.sciencedirect.com/science/article/pii/S0306261915006546.

[16] M. Abdel-Aal, R. Smits, M. Mohamed, K. De Gussem, A. Schellart, S. Tait, Modelling the viability of heat recovery from combined sewers, Water Science \& Technology 70 (2) (2014) 297-306.

[17] J. Elias-Maxil, J. P. van der Hoek, J. Hofman, L. Rietveld, Energy in the urban water cycle: Actions to reduce the total expenditure of fossil fuels with emphasis on heat reclamation from urban water, Renewable and Sustainable Energy Reviews 30 (2014) 808 - 820, ISSN 1364-0321, doi: \bibinfo\{doi\}\{http://dx.doi.org/10.1016/j.rser.2013.10.007\}, URL http://www.sciencedirect. com/science/article/pii/S1364032113007065.

[18] A. Hepbasli, E. Biyik, O. Ekren, H. Gunerhan, M. Araz, A key review of wastewater source heat pump (WWSHP) systems, Energy Conversion and Management 88 (2014) 700 - 722, ISSN 01968904, doi: \bibinfo\{doi\}\{http://dx.doi.org/10.1016/j.enconman.2014.08.065\}, URL http://www . sciencedirect.com/science/article/pii/S0196890414007900.

[19] M. Brand, J. E. Thorsen, S. Svendsen, Numerical modelling and experimental measurements for a low-temperature district heating substation for instantaneous preparation of $\{\mathrm{DHW}\}$ with respect to service pipes, Energy 41 (1) (2012) 392 - 400, ISSN 0360-5442, doi: $\backslash$ bibinfo $\{$ doi $\}\{$ http://dx.doi. org/10.1016/j.energy.2012.02.061\}, URL http://www.sciencedirect.com/science/article/ pii/S0360544212001752, 23rd International Conference on Efficiency, Cost, Optimization, Simulation and Environmental Impact of Energy Systems, \{ECOS\} 2010.

[20] S. Perry, J. Klemes, I. Bulatov, Integrating waste and renewable energy to reduce the carbon footprint of locally integrated energy sectors, Energy 33 (10) (2008) 1489 - 1497, ISSN 0360-5442, doi:〈bibinfo\{doi\}\{http://dx.doi.org/10.1016/j.energy.2008.03.008\}, URL http: //www.sciencedirect.com/science/article/pii/S0360544208000911, \{PRES\} '07 10th Conference on Process Integration, Modelling and Optimisation for Energy Saving and Pollution Reduction 10th Conference on Process Integration, Modelling and Optimisation for Energy Saving and Pollution Reduction.

[21] L. Girardin, F. Marechal, M. Dubuis, N. Calame-Darbellay, D. Favrat, EnerGis: A geographical information based system for the evaluation of integrated energy conversion systems in urban areas, Energy 35 (2) (2010) 830 - 840, ISSN 0360-5442, doi: bibinfo\{doi\}\{http://dx.doi.org/ 10.1016/j.energy.2009.08.018\}, URL http://www.sciencedirect.com/science/article/pii/ S0360544209003582.

[22] S. Kordana, D. Slys, J. Dziopak, Rationalization of water and energy consumption in shower systems of single-family dwelling houses, Journal of Cleaner Production 82 (2014) 58 - 69, ISSN 0959-6526, doi: \bibinfo\{doi\}\{http://dx.doi.org/10.1016/j.jclepro.2014.06.078\}, URL http: //www.sciencedirect.com/science/article/pii/S0959652614006660. 
[23] C. Weber, Multi-objective design and optimization of district energy systems including polygeneration energy conversion technologies, Ph.D. thesis, EPFL, Lausanne, Switzerland, URL http://biblion.epfl.ch/EPFL/theses/2008/4018/EPFL_TH4018.pdf, 2008.

[24] S. Fazlollahi, Decomposition optimization strategy for the design and operation of district energy system, Ph.D. thesis, EPFL, Lausanne, Switzerland, 2014.

[25] B. Elmegaard, T. S. Ommen, M. Markussen, J. Iversen, Integration of Space Heating and Hot Water Supply in Low Temperature District Heating, Energy and Buildings (2015) ISSN 0378-7788, doi: \bibinfo\{doi\}\{http://dx.doi.org/10.1016/j.enbuild.2015.09.003\}, URL http: //www.sciencedirect.com/science/article/pii/S0378778815302449.

[26] J. Thorsen, H. Kristjansson, Cost considerations on storage tank versus heat exchanger for hot water preparation, in: 10th International Symposium on District Heating and Cooling, 2006, Hanover, Germany, Sept. 3-5, 2006, URL http://heating.danfoss.com/PCMPDF/VFKQA202_ Cost_considerations.pdf, 2006.

[27] C. Christiansen, A. Rosa, M. Brand, P. Olsen, J. Thorsen, Results and experiences from a 2 - year study with measurements on a low - temperature DH system for low energy buildings, in: 13th International Symposium on District Heating and Cooling 2012, Copenhagen, Denmark, Sept. 3-4, 2012, URL https://setis.ec.europa.eu/energy-research/sites/default/files/project/ docs/VFHZC102_results-and-experiences_lores_0.pdf, 2012.

[28] A. D. Rosa, R. Boulter, K. Church, S. Svendsen, District heating (DH) network design and operation toward a system-wide methodology for optimizing renewable energy solutions (SMORES) in Canada: A case study, Energy 45 (1) (2012) 960 - 974, ISSN 0360-5442, doi: \bibinfo\{doi\}\{http: //dx.doi.org/10.1016/j.energy.2012.06.062\}, URL http://www.sciencedirect.com/science/ article/pii/S0360544212005142, the 24th International Conference on Efficiency, Cost, Optimization, Simulation and Environmental Impact of Energy, \{ECOS\} 2011.

[29] O. Guerra Santin, L. Itard, H. Visscher, The effect of occupancy and building characteristics on energy use for space and water heating in Dutch residential stock, Energy and Buildings 41 (11) (2009) 1223-1232, ISSN 03787788, doi: \bibinfo\{doi\}\{10.1016/j.enbuild.2009.07.002\}.

[30] B. Howard, L. Parshall, J. Thompson, S. Hammer, J. Dickinson, V. Modi, Spatial distribution of urban building energy consumption by end use, Energy and Buildings 45 (0) (2012) 141 151, ISSN 0378-7788, doi: \bibinfo\{doi\}\{http://dx.doi.org/10.1016/j.enbuild.2011.10.061\}, URL http://www.sciencedirect.com/science/article/pii/S037877881100524X.

[31] A. Mastrucci, O. Baume, F. Stazi, U. Leopold, Estimating energy savings for the residential building stock of an entire city: A GIS-based statistical downscaling approach applied to Rotterdam, Energy and Buildings 75 (0) (2014) 358 - 367, ISSN 0378-7788, doi: \bibinfo\{doi $\}\{$ http: //dx.doi.org/10.1016/j.enbuild.2014.02.032\}, URL http://www.sciencedirect.com/science/ article/pii/S0378778814001467.

[32] M. H. Wahlstrom, B. Harsman, Residential energy consumption and conservation, Energy and Buildings 102 (2015) 58-66, ISSN 03787788, doi: bibinfo\{doi $\}\{10.1016 /$ j.enbuild.2015.05.008\}, URL http://linkinghub.elsevier.com/retrieve/pii/S0378778815003710.

[33] N. Schueler, A. Mastrucci, A. Bertrand, J. Page, F. Marechal, Heat demand estimation for different building types at regional scale considering building parameters and urban topography, in: 6th International Building Physics Conference, Energy Procedia, Elsevier, 2015. 
[34] N. Fumo, M. R. Biswas, Regression analysis for prediction of residential energy consumption, Renewable and Sustainable Energy Reviews 47 (2015) 332-343, ISSN 13640321, doi: $\backslash$ bibinfo\{doi\}\{10.1016/j.rser.2015.03.035\}, URL http://linkinghub.elsevier.com/retrieve/ $\mathrm{pii} / \mathrm{S} 1364032115001884$.

[35] E.-R. Schramek (Ed.), Taschenbuch für Heizung und Klimatechnik 07/08, Oldenbourg Industrieverlag München, 73 edn., 2007.

[36] H. Becker, F. Marechal, Targeting industrial heat pump integration in multi-period problems, in: I. A. Karimi, R. Srinivasan (Eds.), 11th International Symposium on Process Systems Engineering, vol. 31 of Computer Aided Chemical Engineering, Elsevier, 415 - 419, doi: bibinfo\{doi\}\{http://dx.doi.org/10.1016/B978-0-444-59507-2.50075-5\}, URL http://www . sciencedirect.com/science/article/pii/B9780444595072500755, 2012.

[37] S. Fazlollahi, G. Becker, F. Maréchal, Multi-objectives, multi-period optimization of district energy systems: II Daily thermal storage, Computers \& Chemical Engineering (0) (2013) -, ISSN 0098-1354, doi: \bibinfo\{doi\}\{http://dx.doi.org/10.1016/j.compchemeng.2013.10.016\}, URL http://www.sciencedirect.com/science/article/pii/S0098135413003384.

[38] S. Fazlollahi, N. Schueler, F. Marechal, A solid thermal storage model for the optimization of buildings operation strategy, Energy 88 (2015) 209 - 222, ISSN 0360-5442, doi: bibinfo\{doi $\}\{$ http: //dx.doi.org/10.1016/j.energy.2015.04.085\}, URL http://www.sciencedirect.com/science/ article/pii/S0360544215005526.

[39] H. Tol, S. Svendsen, Improving the dimensioning of piping networks and network layouts in lowenergy district heating systems connected to low-energy buildings: A case study in Roskilde, Denmark, Energy 38 (1) (2012) 276 - 290, ISSN 0360-5442, doi:〈bibinfo\{doi\}\{http://dx.doi.org/ 10.1016/j.energy.2011.12.002\}, URL http://www.sciencedirect.com/science/article/pii/ S0360544211007961.

[40] M. Gaderer, Wärmeversorgung mit fester Biomasse bei kleiner Leistung, Ph.D. thesis, Technische Universtiät München, URL https://mediatum.ub.tum.de/doc/630149/630149.pdf, 2007.

[41] R. Spur, D. Fiala, D. Nevrala, D. Probert, Influence of the domestic hot-water daily drawoff profile on the performance of a hot-water store, Applied Energy 83 (7) (2006) 749 773, ISSN 0306-2619, doi: \bibinfo\{doi\}\{http://dx.doi.org/10.1016/j.apenergy.2005.07.001\}, URL http://www.sciencedirect.com/science/article/pii/S0306261905001066.

[42] L. Wong, K. Mui, Y. Guan, Shower water heat recovery in high-rise residential buildings of Hong Kong, Applied Energy 87 (2) (2010) 703-709, doi: \bibinfo\{doi $\}\{10.1016 / j$ japenergy. 2009.08.008\}, URL http://www.scopus.com/inward/record.url?eid=2-s2.0-75449109881\& partnerID $=40 \& m d 5=e 587 \mathrm{a} 0 \mathrm{~d} 2 \mathrm{a} 3 \mathrm{c} 2 \mathrm{~b} 92908 \mathrm{eb} 97 \mathrm{cb} 7 \mathrm{~d} 96026 \mathrm{c}$.

[43] W. DeOreo, J. Heaney, P. Mayer, Flow trace analysis to assess water use, Journal of the American Water Works Association 88 (1).

[44] R. Hendron, J. Burch, Development of Standardized Domestic Hot Water Event Schedules for Residential Buildings, in: Energy Sustainability 2007, Long Beach, California, Jun 27 - 30, 2007, URL http://www.nrel.gov/docs/fy08osti/40874.pdf, 2007.

[45] R. Neunteufel, L. Richard, R. Perfler, Wasserverbrauch und Wasserbedarf - Auswertung empirischer Daten zum Wasserverbrauch, Tech. Rep., Bundesministerium für Landund Forstwirtschaft, Umwelt und Wasserwirtschaft, URL http://www.umweltfoerderung .at/ uploads/wasserverbrauch_und_wasserbedarf.pdf, in German, 2012. 
[46] C. D. Beal, R. A. Stewart, K. Fielding, A novel mixed method smart metering approach to reconciling differences between perceived and actual residential end use water consumption, Journal of Cleaner Production 60 (2013) 116 - 128, ISSN 0959-6526, doi: bibinfo\{doi\}\{http://dx.doi.org/ 10.1016/j.jclepro.2011.09.007\}, URL http://www.sciencedirect.com/science/article/pii/ S0959652611003386, special Volume: Water, Women, Waste, Wisdom and Wealth.

[47] R. Cahill, J. R. Lund, B. DeOreo, J. Medellin-Azuara, Household water use and conservation models using Monte Carlo techniques, Hydrology and Earth System Sciences 17 (10) (2013) 3957-3967, doi: \bibinfo\{doi\}\{10.5194/hess-17-3957-2013\}, URL http://www . hydrol-earth-syst-sci.net/17/3957/2013/.

[48] S. J. Kenway, R. Scheidegger, T. A. Larsen, P. Lant, H.-P. Bader, Water-related energy in households: A model designed to understand the current state and simulate possible measures, Energy and Buildings 58 (2013) 378 - 389, ISSN 0378-7788, doi: \bibinfo\{doi\}\{http://dx.doi.org/ 10.1016/j.enbuild.2012.08.035\}, URL http://www.sciencedirect.com/science/article/pii/ S0378778812004392.

[49] K. Rathnayaka, H. Malano, S. Maheepala, B. c. George, B. Nawarathna, M. Arora, P. Roberts, Seasonal demand dynamics of residential water end-uses, Water (Switzerland) 7 (1) (2015) 202-216, doi: bibinfo\{doi $\{10.3390 /$ w7010202\}, URL http://www . scopus . com/inward/record. url?eid=2-s2.0-84920897056\&partnerID=40\&md5=299b6245f $833 f$ faa8a4267 f 17896868 a.

[50] A. A. Makki, R. A. Stewart, C. D. Beal, K. Panuwatwanich, Novel bottom-up urban water demand forecasting model: Revealing the determinants, drivers and predictors of residential indoor end-use consumption, Resources, Conservation and Recycling 95 (2015) 15 37, ISSN 0921-3449, doi: bibinfo\{doi\}\{http://dx.doi.org/10.1016/j.resconrec.2014.11.009\}, URL http://www.sciencedirect.com/science/article/pii/S0921344914002419.

[51] T.-A. Koiv, A. Toode, Trends in domestic hot water consumption in Estonian apartment buildings, Proc. Estonian Acad. Sci. Eng. 12 (1) (2006) 72-80.

[52] E. J. M. Blokker, J. H. G. Vreeburg, J. C. Van Dijk, Simulating Residential Water Demand with a Stochastic End-Use Model., Journal of Water Resources Planning \& Management 136 (1) (2010) 19 - 26, ISSN 07339496, URL http://search.ebscohost.com.proxy.bnl.lu/login. asp $x$ ?direct $=$ true\&db=iih\&AN=47086106\&site=ehost - live\&scope=site.

[53] A. Gutierrez-Escolar, A. Castillo-Martinez, J. M. Gomez-Pulido, J.-M. Gutierrez-Martinez, E. Garcia-Lopez, A New System for Households in Spain to Evaluate and Reduce Their Water Consumption, Water 6 (1) (2014) 181, ISSN 2073-4441, doi: $\backslash$ bibinfo $\{$ doi $\}\{10.3390 /$ w6010181 $\}$, URL http://www.mdpi.com/2073-4441/6/1/181.

[54] R. Cobacho, F. Arregui, J. Parra, E. Cabrera Jr., Improving efficiency in water use and conservation in Spanish hotels, Water Science and Technology: Water Supply 5 (3-4) (2005) 273-279, URL http://www.scopus.com/inward/record.url?eid=2-s2. $0-29144442440 \&$ partnerID $=40 \& \mathrm{md} 5=\mathrm{dc} 1 \mathrm{a} 841 \mathrm{afd} 74 \mathrm{cba} 7 \mathrm{c} 885 \mathrm{dbc} 98 \mathrm{~b} 841 \mathrm{a} 74$.

[55] E. J. M. Blokker, E. J. Pieterse-Quirijns, J. H. G. Vreeburg, J. C. van Dijk, Simulating Nonresidential Water Demand with a Stochastic End-Use Model., Journal of Water Resources Planning \& Management 137 (6) (2011) 511 - 520, ISSN 07339496, URL http://search.ebscohost.com.proxy.bnl.lu/login.aspx?direct=true\&db= iih\&AN=69734587\&site=ehost - live\&scope=site. 
[56] S. Hokoi, D. Ogura, X. Fu, Y. Rao, Field survey on energy consumption due to hot water supply and cooking in Nanjing and Hefei, China, Frontiers of Architectural Research 2 (2) (2013) 134 - 146, ISSN 2095-2635, doi: \bibinfo\{doi\}\{http://dx.doi.org/10.1016/j.foar.2013.03.001\}, URL http://www. sciencedirect.com/science/article/pii/S2095263513000198.

[57] PostgreSQL, PostgreSQL: an open source object-relational database system, URL http://www . postgresql.org, 2015.

[58] Statistik Austria, Ausstattungsgrad der Haushalte - Bundesländerergebnisse, URL http://www.statistik.at/web_de/statistiken/menschen_und_gesellschaft/soziales/ ausstattung_privater_haushalte/059000.html, in German, last accessed: 11/09/2015, 2011.

[59] INSEE, Équipement des ménages en biens durables selon le type de ménage, URL http://www . insee.fr/fr/themes/tableau.asp?reg_id=0\&ref_id=NATnon05155, in French, last accessed: 11/09/2015, 2012.

[60] Statistisches Bundesamt, Ausstattung privater Haushalte mit elektrischen Haushalts- und sonstigen Geräten - Deutschland, URL https://www.destatis.de/DE/ZahlenFakten/ GesellschaftStaat/EinkommenKonsumLebensbedingungen/AusstattungGebrauchsguet ern/ Tabellen/Haushaltsgeraete_D.html, in German, last accessed: 08/09/2015, 2015.

[61] Statec, Population census: household appliances on the february 1st , 2011, URL http: //www. statistiques.public.lu/stat/tableviewer/document. aspx?ReportId=8604, last accessed: 09/01/2015, 2011.

[62] B. Morgenthaler, A. Grossenbacher, E. Burnier, Statistical Data on Switzerland 2015, Tech. Rep., Federal Statistical Office, URL http://www.bfs.admin.ch/bfs/portal/en/index/news/ publikationen.Document.189954.pdf, 2015.

[63] Eurostat, Share of total population having neither a bath, nor a shower in their dwelling (ilcmdho02), URL http://ec.europa.eu/eurostat/en/web/products-datasets/-/ilc_mdho02, last accessed: 07/09/2015, 2015.

[64] INSEE, Confort sanitaire et chauffage des résidences principales en 2006, URL http://www. insee.fr/fr/themes/tableau.asp?reg_id=0\&ref_id=natsos05204, in French, last accessed: 11/09/2015, 2006.

[65] E. Pieterse-Quirijns, E. Blokker, E. Van Der Blom, J. c. Vreeburg, Modelling characteristic values for non-residential water demand, in: Water Distribution System Analysis 2010, Tucson, Arizona, USA, Sept. 12-15, 2010, 2010.

[66] E. J. M. Blokker, E. J. Pieterse-Quirijns, J. H. G. Vreeburg, J. C. van Dijk, Closure to 'Simulating Nonresidential Water Demand with a Stochastic End-Use Model' by E. J. M. Blokker, E. J. Pieterse-Quirijns, J. H. G. Vreeburg, and J. C. van Dijk., Journal of Water Resources Planning \& Management 139 (3) (2013) 347 - 348, ISSN 07339496, URL http://search.ebscohost.com.proxy.bnl.lu/login.aspx?direct=true\&db= iih\&AN=86929080\&site=ehost - live\&scope=site.

[67] C. Jones, Hotels take the bath out of bathrooms, URL http://usatoday.com/MONEY/ usaedition/2011-05-20-hotel1tubs19_ST_U.htm, last accessed: 11/09/2015, 2011.

[68] Vienna Tourist Board, List of all accommodations, URL http://www.wien.info/en/hotel/ suche, last accessed: 17/09/2015, 2015. 
[69] ONT, www.visitluxembourg.com, URL http://www.visitluxembourg.com/en/eat-sleep/ hotels, 2015.

[70] Switzerland Tourism, www.myswitzerland.com, URL http://www.myswitzerland.com, last accessed: $15 / 09 / 2015,2015$.

[71] Eurostat, Number of establishments, bedrooms and bed-places by NUTS 2 regions (tour-capnat)), URL http://ec.europa.eu/eurostat/web/products-datasets/-/tour_cap_nat, last accessed: $15 / 09 / 2015,2015$.

[72] Eurostat, Net occupancy rate of bed-places and bedrooms in hotels and similar accommodation(tour-occ-mnor), URL http://ec.europa.eu/eurostat/en/web/ products-datasets/-/TOUR_OCC_MNOR, last accessed: 15/09/2015, 2015.

[73] Bundesministerium fur Arbeit, Soziales und Kosumentenschutz, Alten-/Pflegeheime, URL https://www .infoservice.sozialministerium.at/InfoService2/, in German, last accessed: 17/09/2015, 2015.

[74] Capgeris, Hebergement personnes agees, URL http://www.capgeris.com, in French, last accessed: 17/09/2015, 2015.

[75] Privatinstitut für Transparenz im Gesundheitswesen GmbH, Deutsches Seniorenportal, URL http://www.deutsches-seniorenportal.de, in German, last accessed: 17/09/2015, 2015.

[76] A. Haederli, D. Balmer, C. Boss, O. Zihlmann, J. Schmidli, Atlas der Altersheime, URL http: //altersheim-atlas.ch, in German, last accessed: 17/09/2015, 2015.

[77] Luxsenior, Releve des services pour personnes agees au Luxembourg, Tech. Rep., Luxsenior, URL http://www. luxsenior.lu/pdf/adresses.pdf, 2015.

[78] Statec, Infrastructures pour personnes agées 2002 - 2012, URL http://www.statistiques. public.lu/stat/TableViewer/tableViewHTML . aspx?ReportId=562\&IF_Language=fra\& MainTheme=3\&FldrName=3\&RFPath=117, last accessed: 15/09/2015, 2013.

[79] J. Evans, P. Evans, C. Babatope, European healthcare - care homes report 2014, Tech. Rep., Knight Frank, URL http://content.knightfrank.com/research/656/documents/en/ 2014-2257.pdf, last accessed: 15/09/2015, 2014.

[80] Service des travaux municipaux, GIS data set, obtained 06/2015, 2015.

[81] PostGIS Project, PostGIS, URL http://postgis.org, 2015.

[82] Statec, Household budget survey 2008-2013, URL http://www.statistiques.public.lu/ en/surveys/espace-households/budget-household/index.html, last accessed: 11/12/2014, 2015.

[83] Luxemburgish Parliament, Règlement grand-ducal du 26 mai 2014 modifiant 1 . le règlement grand-ducal modifié du 30 novembre 2007 concernant la performance énergétique des bâtiments d'habitation; 2. le règlement grand-ducal modifié du 31 août 2010 concernant la performance énergétique des bâtiments fonctionnels; et 3. le règlement grand-ducal du 27 février 2010 concernant les installations à gaz, 2014.

[84] Luxemburgish Parliament, Règlement grand-ducal du 31 août 2010 concernant la performance énergétique des bâtiments fonctionnels, 2010. 
[85] Statec, Population census 2011, URL http://www.statistiques.public.lu/en/methodology/ methodes/population-employment/Pop-logement/recensement-population/index.html? highlight=census, last accessed: 09/01/2015, 2011.

[86] Booking.com, URL www .booking.com, last accessed: 23/10/2015, 2015.

[87] Servior, www.servior.lu, URL http://www.servior.lu/fr/services/sites, in German, last accessed: $15 / 09 / 2015,2015$.

[88] R Core Team, R: A Language and Environment for Statistical Computing, R Foundation for Statistical Computing, Vienna, Austria, URL https://www.R-project.org, 2015.

[89] J. Z. Kolter, J. Ferreira, A Large-scale Study on Predicting and Contextualizing Building Energy Usage, Proceedings of the Conference on Artificial Intelligence (AAAI), Special Track on Computational Sustainability and AI, 2011 (2011) 8.

[90] Administration de la navigation aérienne, Hourly outdoor temperature Findel-airport, obtained 06/2015, 2015 .

[91] P. Varbanov, Z. Fodor, J. Klemes, Total Site targeting with process specific minimum temperature difference (dT min), Energy 44 (1) (2012) 20-28, URL http://www . scopus . com/inward/record. url?eid=2-s2 . 0-84864353726\&partnerID=40\&md5=823c9594a83fbb59011d48f7ab76be77.

[92] S. Fazlollahi, G. Becker, F. Maréchal, Multi-objectives, multi-period optimization of district energy systems: III. Distribution networks, Computers \& Chemical Engineering 66 (0) (2014) 82 - 97, ISSN 0098-1354, doi:〈bibinfo\{doi\}\{http://dx.doi.org/10.1016/j.compchemeng.2014.02. 018\}, URL http://www.sciencedirect.com/science/article/pii/S0098135414000507, selected papers from ESCAPE-23 (European Symposium on Computer Aided Process Engineering - 23), 9-12 June 2013, Lappeenranta, Finland.

[93] A. Hesaraki, E. Bourdakis, A. Ploskic, S. Holmberg, Experimental study of energy performance in low-temperature hydronic heating systems, Energy and Buildings 109 (2015) 108 114, ISSN 0378-7788, doi: \bibinfo\{doi\}\{http://dx.doi.org/10.1016/j.enbuild.2015.09.064\}, URL http://www. sciencedirect.com/science/article/pii/S0378778815303042.

[94] H. Becker, F. Maréchal, A. Vuillermoz, Process integration and opportunities for heat pumps in industrial processes, International Journal of Thermodynamics 14 (2) (2011) 59-70, doi: \bibinfo\{doi\}\{10.5541/ijot.260\}, URL http://www.scopus.com/inward/record.url?eid= $2-\mathrm{s} 2.0-79958155332 \&$ partner ID $=40 \& \mathrm{md} 5=\mathrm{f} 5535 \mathrm{f} 1 \mathrm{eff} \mathrm{a} 42 \mathrm{~b} 2 \mathrm{~d} 2 \mathrm{c} 38527352 \mathrm{a} 78 \mathrm{cb} 2$.

[95] Enovos, Electricity price Naturstroum, URL http://www.enovos.lu/en/individuals/ electricity/naturstroum, last accessed: 25/08/2015, 2015.

[96] S. Maas, D. Waldmann, A. Zuerbes, J. Scheuren, Wie viel der LuLuxemburg wirklich verbraucht..., Revue technique Luxembourgeoise 4 (2007) 211 - 216, URL http://www.krk.lu/attachments/ article/40/Artikel_Was\%20verbraucht\%20ein\%20Luxemburger\%20wirklich.pdf.

[97] A. Merzkirch, T. Hoos, F. Maas, F. Scholzen, D. Waldmann, Wie genau sind unsere Energiepaesse?, Bauphysik 36 (1) (2014) 40-43, ISSN 1437-0980, doi: \bibinfo\{doi $\}\{10.1002 /$ bapi. 201410007\}, URL http://dx.doi.org/10.1002/bapi.201410007.

[98] T. R. Tooke, M. van der Laan, N. C. Coops, Mapping demand for residential building thermal energy services using airborne LiDAR, Applied Energy 127 (0) (2014) 125 - 134, ISSN 0306-2619, doi: \bibinfo\{doi\}\{http://dx.doi.org/10.1016/j.apenergy.2014.03.035\}, URL http:// www.sciencedirect.com/science/article/pii/S0306261914002657. 


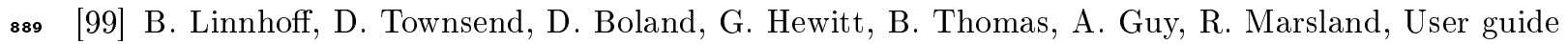
on process integration for the efficient use of energy, Tech. Rep., Institution of chemical engineers, $891 \quad$ Rugby, U.K., 1982. 